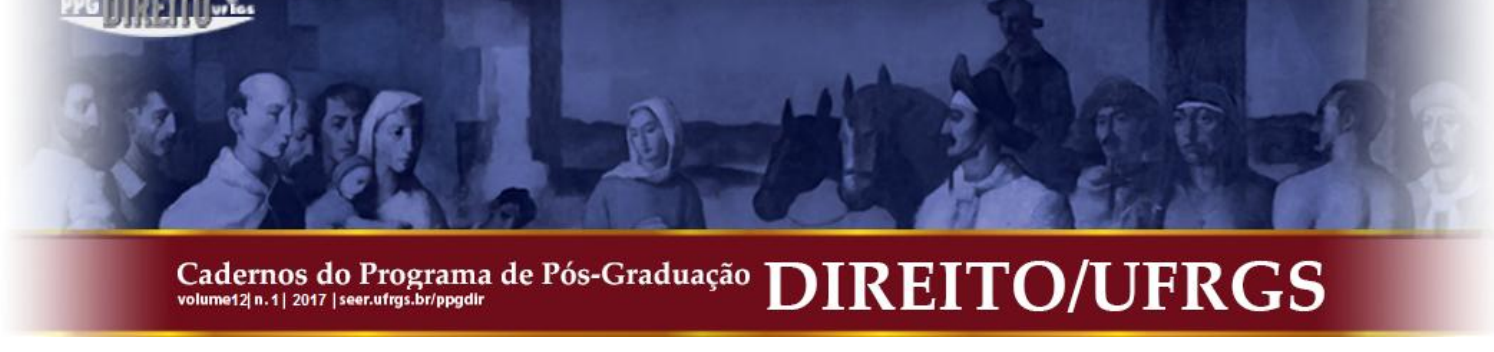

\title{
ESTUDO DIRIGIDO AO LATROCÍNIO: UMA ABORDAGEM AO DELITO NO MUNICÍPIO DE GRAVATAÍ NO PERÍODO DE 2003 A 2013
}

\author{
LARCENY DIRECTED STUDY: AN APPROACH TO CRIME IN MUNICIPALITY OF \\ GRAVATAÍ IN THE PERIOD OF 2003 TO 2013
}

\begin{abstract}
RESUMO: A pesquisa teve como objetivo problematizar cursos de ação exercidos por autores de crime de latrocínio na cidade de Gravataí e a existência de ocorrências violentas na execução da pena destes autores. Para isso, primeiramente buscou-se identificar quantos crimes foram elucidados no Município de Gravataí no período de 2003 a 2013. Após esse levantamento, averiguou-se como e onde esses autores cumprem a pena a fim de rastrear a existência ou não de atitudes violentas no estabelecimento prisional que possam ser caracterizadas como uma extensão da violência. Para responder ao objetivo da pesquisa foram adotados três trajetos: no primeiro relatou-se o contexto da violência na região metropolitana, bem como, um possível parâmetro entre os autores selecionados, no segundo analisou-se a execução penal desses autores e no terceiro trajeto verificou-se de que maneira a Administração Carcerária aborda as condutas no cárcere. No cenário da pesquisa foram utilizadas as opiniões de profissionais que lidam diariamente com o tema violência tanto na sociedade como no ambiente prisional. Não foram verificadas atitudes que demonstrem uma continuidade da violência no ambiente prisional a partir de duas assertivas: primeiro porque os autores analisados não apresentaram condutas violentas no curso da sua execução penal e segundo porque, aparentemente, a Administração Carcerária possui um controle sobre as atitudes violentas no cárcere. Por fim, foi realizado esboço crítico sobre os resultados da pesquisa.
\end{abstract}

PALAVRAS-CHAVE: Violência. Comportamento. Latrocínio. Cárcere.

SUMÁRIO: Introdução. 1 Sobre o Latrocínio. 2 Metodologia. 3 O Retrato do Latrocínio no Município de Gravataí/RS. 4 A Execução Penal e a Situação Atual dos Autores. Considerações Finais. Referências.

\section{INTRODUÇÃO}

Disposto na legislação brasileira no rol dos crimes contra o patrimônio e classificado como um crime hediondo, o latrocínio abrange ao mesmo tempo dois bens jurídicos tutelados:

\footnotetext{
* Graduada em Direito pela Campanha Nacional de Escolas da Comunidade (CNEC), Rio Grande do Sul.

** Pós-Doutorando, Doutor e Mestre em Ciências Criminais pela Pontifícia Universidade Católica do Rio Grande do Sul (PUC-RS). Professor Colaborador do programa de Pós-Graduação em Ciências Criminais da Pontifícia Universidade Católica do Rio Grande do Sul (PUC-RS). Professor da Faculdade de Direito da Campanha Nacional de Escolas da Comunidade (CNEC), Rio Grande do Sul.
}

ABSTRACT: This study aimed to investigate if the violent attitude manifest in the course of execution of the sentence. For this, first sought to identify how many crimes have been elucidated in the municipality of Gravatai from 2003 to 2013. After this survey, it was the existence of violent attitudes prison that can be characterized as an extension of violence. To met the objective of the research there in the metropolitan area, as well as a possible parameter of the selected authors, the second analyzed the criminal enforcement of Administration addresses the conduct in prison. In the scenario the research were used the opinions of professionals who daily deal with the topic violence both in society and in the prison demonstrate a continuity of violence in the prison environment from two assertions: first because the authors analyzed showed no violent because, apparently, the Prison Administration has control over violent attitudes in prison.

\section{9}




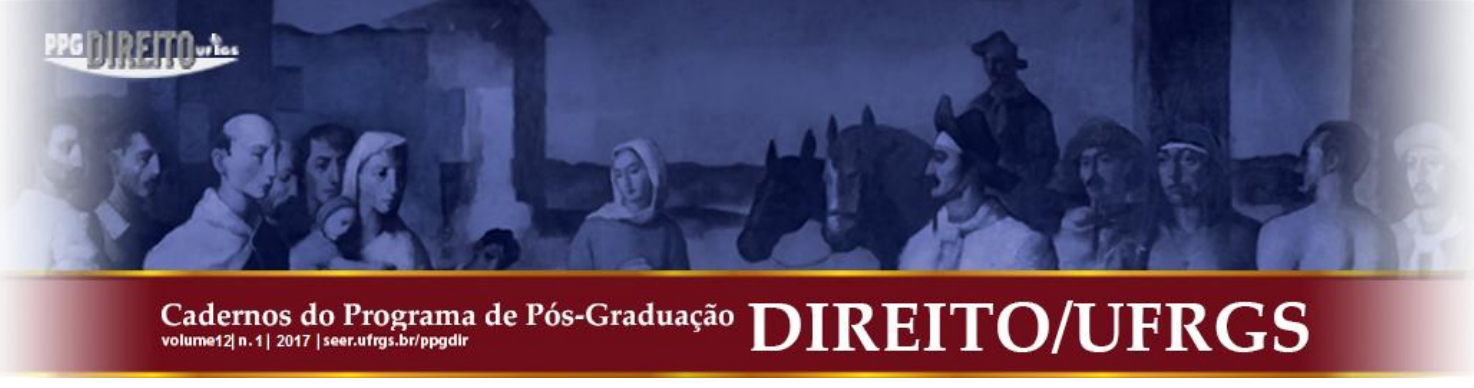

o patrimônio e a integridade física da pessoa. Ainda, pode-se supor que nem todos os autores são violentos, ou exerceram de violência ao praticar o delito. Contudo, conforme o decorrer desta pesquisa, verificou-se que há enorme complexidade quanto a conduta do(s) autor(es), o patrimônio auferido e os fatores que desencadearam tais atitudes.

Em relação à metodologia, a forma utilizada para esse estudo envolveu a coleta e análise de dados, pesquisa qualitativa e quantitativa, além de pesquisa bibliográfica. Para esse fim, delimitou-se a região a ser estudada, bem como, os autores a serem analisados. Em relação ao perímetro, a escolha foi à região metropolitana, precisamente o Município de Gravataí, utilizando-se como critério a busca de todos processos com trânsito em julgado na Comarca entre o período de janeiro de 2003 a dezembro de 2013. A porção encontrada não contabiliza aqueles crimes que mesmo investigados não foram concluídos ou ainda aqueles que sequer foram descobertos no Município, porém cabe ainda mencionar, que a presente análise parte da totalidade dos casos elucidados no período.

\section{SOBRE O LATROCÍNIO}

Historicamente a palavra latrocínio vem do Direito Romano como "uma estreita ligação com o chamado homicídio mediante paga, [...] como modalidade de homicídio praticado por motivo torpe ${ }^{1 "}$. Na Roma Antiga, o latrocínio chegou a ser conceituado como um delito mercenário no qual o executor recebia para tal ação uma recompensa ou ainda um pagamento.

Segundo Marcelo Fortes Barbosa, a tradicional expressão latrocínio, utilizada para classificar a forma mais gravosa do crime de roubo, "foi prevista no art. 359 do Código de 1890 e reproduzida na Consolidação das Leis Penais com numeração e letra idêntica" ${ }^{2}$.

Ainda, de acordo com o autor, a evolução histórica do latrocínio passou por algumas etapas:

No Brasil, o latrocínio passou a integrar o elenco dos crimes previstos no famoso livro V das Ordenações Filipinas, por meio de um alvará de 20 de outubro de 1763 , e, portanto, a partir de então, passou a ser punido sendo certo que a pena imposta era a morte por meio de forca ${ }^{3}$.

\footnotetext{
${ }^{1}$ BARBOSA, Marcelo Fortes. Latrocínio. 1. ed. São Paulo. Malheiros. 1997, p. 13.

${ }^{2}$ BARBOSA, Marcelo Fortes. op. cit., p. 13

${ }^{3}$ BARBOSA, Marcelo Fortes. op. cit., p. 15. 


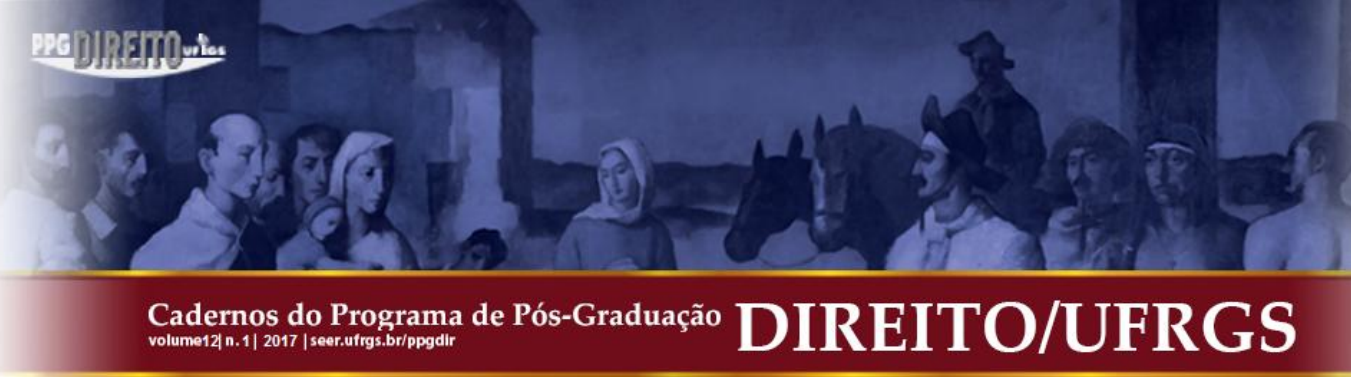

Além disso, refere o autor:

No código de 1830 a modalidade do delito passou a ser punida de maneira mais grave com a pena de homicídio qualificado, tendo como sanção a pena mínima de 20 anos de galés, a média de galés perpétuo e a máxima de morte ${ }^{4}$.

Oliveira diz que "o latrocínio foi especificado, em dispositivo autônomo, no Código Penal de 1890, no art.359, sendo que a estipulação referente à tentativa, prevista no art.360, já provocava acirrados debates na época ${ }^{5}$ ".

Em concordância com a autora enumera Barbosa:

Art.359 - Se para realizar o roubo ou no momento de ser perpetrado, se comete morte:

Penas - de prisão celular de doze a trinta anos.

I - Se cometer-se alguma lesão corporal das especificadas no art. 304:

Penas de prisão celular por quatro a doze anos.

Art.360 - A tentativa de roubo, quando se tiver realizado a violência, ainda que não se opere a tirada da coisa alheia, será punida com as penas do crime se dela resultar a morte de alguém, ou a pessoa ofendida alguma das lesões corporais especificadas no art. $304^{6}$.

O Código de 1940, atualmente em vigor na legislação brasileira, dispõe o roubo qualificado pelo resultado morte no capítulo destinado aos crimes contra o patrimônio, porém a nomenclatura latrocínio, não vem especificada no corpo do texto.

O tipo penal roubo qualificado pela morte é definido como um crime complexo ${ }^{7}$, isto é, o mesmo tipo penal abrange a fusão de dois ou mais crimes (constrangimento, ameaça ou violência acrescido de furto), porém, para que esse crime seja consumado se faz necessária a realização de todo o tipo penal. Ainda, de acordo com a doutrina, o tipo penal pode ser definido como um crime pluriofensivo ${ }^{8}$ visto que, a conduta delituosa atinge ou lesiona mais de um bem jurídico ao mesmo tempo (patrimônio e a integridade física da pessoa).

De acordo com o Código Penal Brasileiro:

Art. 157 - Subtrair coisa móvel alheia, para si ou para outrem, mediante grave ameaça ou violência a pessoa, ou depois de havê-la, por qualquer meio, reduzido à impossibilidade de resistência:

\footnotetext{
${ }^{4}$ BARBOSA, Marcelo Fortes. op. cit., p. 15.

${ }^{5}$ OLIVEIRA, Patrícia de. O Latrocínio na Legislação Brasileira. Revista da Faculdade de Direito da UFG, v. 25, n. 1, 2001. Disponível em: 〈http://www.revistas.ufg.br/index.php/revfd/article/view/12022〉. Acesso em: 27 ago. 2015.

6 BARBOSA, Marcelo Fortes. op. cit., p. 16.

${ }^{7}$ BITENCOURT, Cezar Roberto. Tratado de Direito Penal. Parte Especial 3. 5. ed. São Paulo: Saraiva. 2009.

${ }^{8}$ BITENCOURT, Cezar Roberto. op. cit.
} 


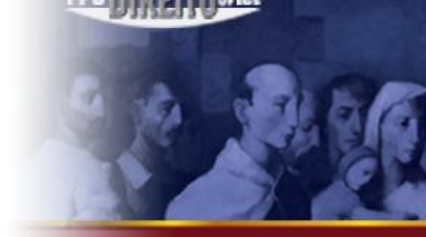

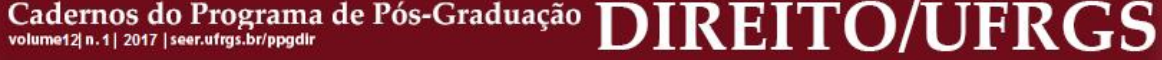

Pena - reclusão, de quatro a dez anos e multa.

[...]

$\S 3^{\circ}$ Se da violência resulta lesão corporal de natureza grave, a pena é de reclusão, de sete a quinze anos, sem prejuízo da multa ${ }^{9}$

Nota-se que o legislador ao tipificar essa agravante no rol dos crimes patrimoniais buscou primeiramente a defesa do patrimônio, pois esta é a intenção inicial do agente subtrair coisa móvel alheia ainda que para isso tenha que atingir o bem jurídico vida.

Desta forma, no latrocínio o autor mata para assegurar a posse do bem subtraído ou para cometer o roubo em si, o que reforça a sua intenção que é meramente patrimonial. É o caso, por exemplo, do autor que atira na vítima para roubar um bem ou rouba e depois atira a fim de impedir que a vítima busque socorro.

Conforme Bitencourt:

Pode-se afirmar, com certa segurança, que doutrina e jurisprudência não discrepam quanto à aplicação do disposto no $\S 3^{\circ}$ tanto ao roubo próprio quanto ao impróprio; é indiferente que o agente produza o resultado mais grave na vítima (lesão grave ou morte) para cometer a subtração, durante a sua execução ou após a sua realização ${ }^{10}$.

Cabe ainda ressaltar que a tipificação contida no $\S 3^{\circ}$ demonstra que o resultado da violência utilizada deve surgir da peculiaridade da intenção do agente, ou seja, seu único objetivo naquele momento é de subtrair o bem e a morte é o meio pelo qual o autor utiliza para alcançar esse objetivo.

Assim discorre a doutrina:

Importa frisar que a morte deve decorrer do emprego de violência pelo agente, com o fim de se apoderar da res ou assegurar a sua posse ou garantir a impunidade do crime. Se, contudo, a morte advier de motivos outros, como ciúmes, vingança, etc., haverá o crime de roubo em concurso com o crime de homicídio ${ }^{11}$.

A segunda peculiaridade deste crime refere-se à modalidade consumação e tentativa. De acordo com o Código Penal diz-se que o crime é consumado quando este reúne todos os elementos da sua definição legal e tentado quando iniciada a execução, não se consuma por circunstâncias alheias à vontade do agente ${ }^{12}$.

\footnotetext{
9 BRASIL. Código Penal Brasileiro. Decreto Lei 2.848, de 07 de Dezembro de 1940. Disponível em: <http://www.planalto.gov.br/ccivil_03/decreto-lei/Del2848compilado.htm>. Acesso em: 29 ago. 2015.

${ }^{10}$ BITENCOURT, Cezar Roberto. op. cit., p. 91.

${ }^{11}$ CAPEZ, Fernando. Curso de Direito Penal. Parte Especial. 8. ed. São Paulo: Saraiva. 2008, p. 448.

12 BRASIL. Código Penal Brasileiro. Decreto Lei 2.848, de 07 de Dezembro de 1940. Art.14, I e II. Disponível em: <http://www.planalto.gov.br/ccivil_03/decreto-lei/Del2848compilado.htm>. Acesso em: 29 ago. 2015. 


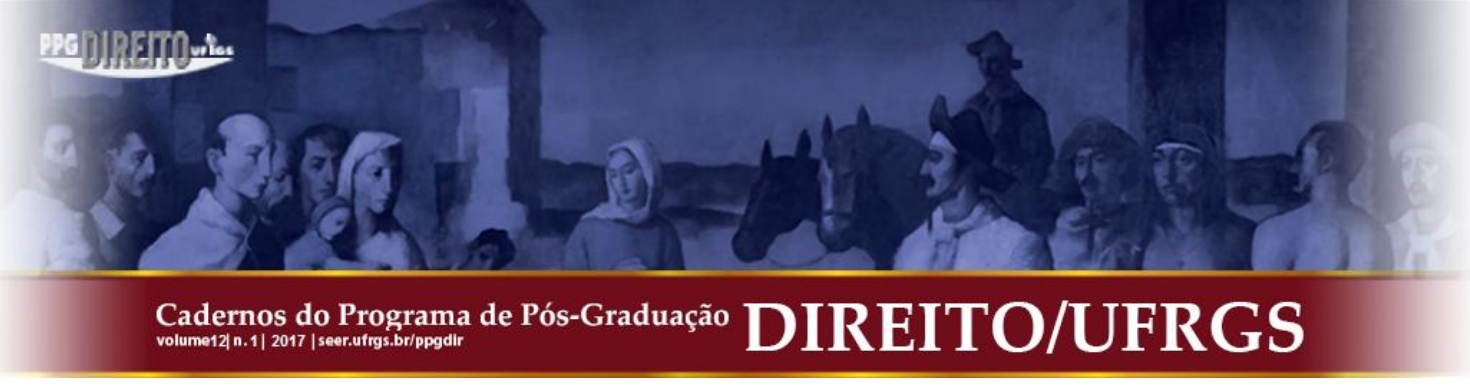

Nesse sentido, temos latrocínio consumado sempre que houver lesão ao bem jurídico vida, ou seja, sempre que houver o resultado morte, não importando se o agente realizou ou não a efetiva subtração patrimonial.

Esse é o entendimento do Supremo Tribunal Federal: "há crime de latrocínio, quando o homicídio se consuma, ainda que não realize o agente a subtração dos bens da vítima ${ }^{13}$.

Consequentemente, observa-se que no crime de latrocínio a particularidade do agente está diretamente ligada a sua intenção que no caso deve ser de subtrair o patrimônio alheio utilizando para esse fim o uso de violência sem mensurar a consequência do seu ato.

Ainda cabe mencionar, que a terminologia latrocínio foi utilizada pelo legislador e inserida na Lei $8.072 / 90^{14}$, tanto na modalidade consumada como tentada ${ }^{15}$. Esses crimes de natureza hedionda são definidos como delitos de máxima potencialidade lesiva, e em razão da sua maior gravidade, são objeto de punições mais severas como forma do Estado assegurar um tratamento mais rigoroso na punição do delito, e ainda, oferecer a sociedade uma resposta mais positiva na contenção dos crimes considerados como mais graves e/ou repugnantes.

Verifica-se que para o caso em tela é imposto ao autor o cumprimento da pena privativa de liberdade em regime fechado, considerado como o mais rigoroso, devendo ser necessariamente cumprido em estabelecimento de segurança máxima ou média, porém sua aplicação deve obrigatoriamente respeitar o limite máximo de 30 (trinta) anos.

Conforme Santos:

O limite máximo de 30 (trinta) decorre da proibição constitucional de penas perpétuas (art. $5^{\circ}$, XLVII, b, CF). A única exceção ocorre na hipótese de condenação por fato punível cometido após o início da execução da pena em que a reunificação determinada pela nova pena aplicada desconsidera o tempo de pena já cumprido ${ }^{16}$.

Ressalta-se ainda, que com o advento da Lei 8072/90 os crimes classificados como hediondos, como é o caso do latrocínio, também poderão ser beneficiados com a progressão

13 BRASIL. Supremo Tribunal Federal. Súmula 610. DJ de 31 de outubro de 1984. Disponível em: <http://www.stf.jus.br/portal/jurisprudencia/menuSumarioSumulas.asp?sumula=2562>. Acesso em: Acesso em 31 ago. 2015.

${ }^{14}$ Lei 8072/90 dispõe sobre os Crimes Hediondos, nos termos do art. $5^{\circ}$, inciso XLIII, da Constituição Federal. BRASIL. Lei $\mathrm{n}^{\circ} 8.072$ de 25 de julho de 1990. Dispõe sobre os Crimes Hediondos, nos termos do art. $5^{\circ}$, inciso XLIII, da Constituição Federal, e determina outras providências. Disponível em: <http://www.planalto.gov.br/CCIVIL_03/leis/L8072.htm>. Acesso em: 31 ago. 2015.

${ }^{15}$ Esta análise acerca do tipo penal é importante para a presente pesquisa, mas as divergências entre os autores não fazem parte do objeto do trabalho.

${ }^{16}$ SANTOS, Juarez Cirino dos. Direito Penal. Parte Geral. 4. ed. Florianópolis: Conceito, 2010, p. 490. 


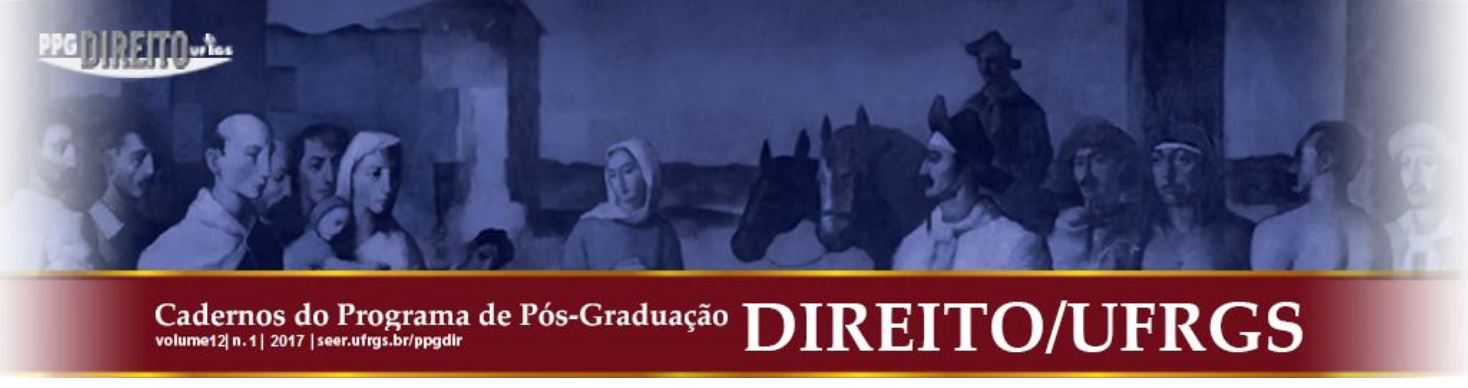

A partir desta primeira amostra o próximo passo foi verificar no site do Tribunal de Justiça do Rio Grande do Sul (TJ/RS) os processos sentenciados de acordo com o artigo $157 \S$ $3^{\circ}$ do Código Penal. Cabe mencionar que, do montante total da primeira amostragem, grande número de processos não possuía sentença cadastrada no site do TJ/RS, sendo necessário que a pesquisa fosse verificada nos dados de $2^{\circ}$ grau - Acórdãos e Decisões Monocráticas. A partir deste recorte obteve-se um total de 30 processos distribuídos e 41 autores.

Com o aprofundamento da pesquisa, constatou-se que durante a instrução processual algumas alterações ocorreram: um autor foi absolvido no Tribunal de Justiça tendo em vista a insuficiência de provas e o não reconhecimento das vítimas em Juízo, um autor foi a óbito durante a instrução processual, um autor foi a óbito não sendo informado o motivo e três autores foram separados do processo principal.

Assim, a pesquisa de campo foi analisada em 25 processos distribuídos para 35 autores. Após esse novo recorte verificou-se onde esses processos estavam arquivados, constatando-se que a grande maioria estava no Arquivo Judicial de Porto Alegre/RS, para onde se encaminhou requerimento para acessá-los. Com o deferimento do Arquivo Judicial e após o desarquivamento iniciou-se a análise dos autos ${ }^{21}$.

Para a verificação e análise das informações que constam nesta pesquisa foram localizados 18 processos físicos (todos no Arquivo Judicial de Porto Alegre), 06 processos pelo sistema Themis (onde as informações foram retiradas da Sentença ou do Acórdão) e, em um processo, não foi possível obter as informações mais relevantes, apenas os dados cadastrados na pasta da execução penal do autor.

\section{O RETRATO DO LATROCÍNIO NO MUNICÍPIO DE GRAVATAÍ/RS}

O Município de Gravataí/RS está inserido na Região Metropolitana de Porto Alegre/RS e como tal, apresenta diariamente um grande fluxo de pessoas que transitam de várias localidades. Além disso, o Município possui divisões urbanas e rurais dentro do mesmo perímetro e essa extensão vem contribuindo para o aumento da insegurança da sociedade local.

21 As visitas ocorreram nos dias 25 de fevereiro de 2016 e 03 de março de 2016. O setor responsável disponibilizou o acesso integral aos autos, com cópia de todas as informações necessárias para o trabalho, com exceção das cópias de cd's que não foram autorizadas. 


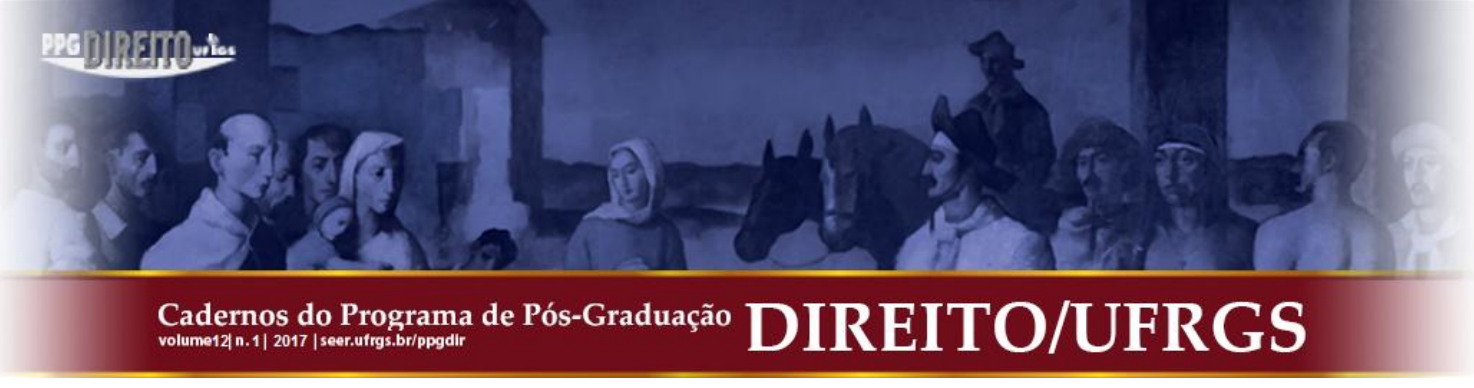

Antes de discutir os principais aspectos da identidade do latrocínio, é importante mencionar que mesmo abordando o retrato da violência não se pode traçar um perfil definitivo para esses autores. Presume-se, que os indicadores encontrados durante a avaliação aos autos possam deduzir algumas características comportamentais, mas longe de defini-las como um padrão. O que se vislumbra é, a partir dos dados coletados, apresentar o contexto do crime de latrocínio na Região Metropolitana, especificamente na localidade selecionada.

O levantamento inicial desta pesquisa está relacionado com a modalidade do próprio tipo penal que apresenta em seu enquadramento as particularidades consumação e tentativa. Dos 25 processos analisados, verificou-se que em 14 casos a vítima foi a óbito (o que configura o crime como latrocínio consumado) e em 11 casos, o crime foi caracterizado como tentado (não havendo a morte da vítima) independentemente da subtração do bem patrimonial. Esta explanação resta demonstrada no gráfico abaixo:

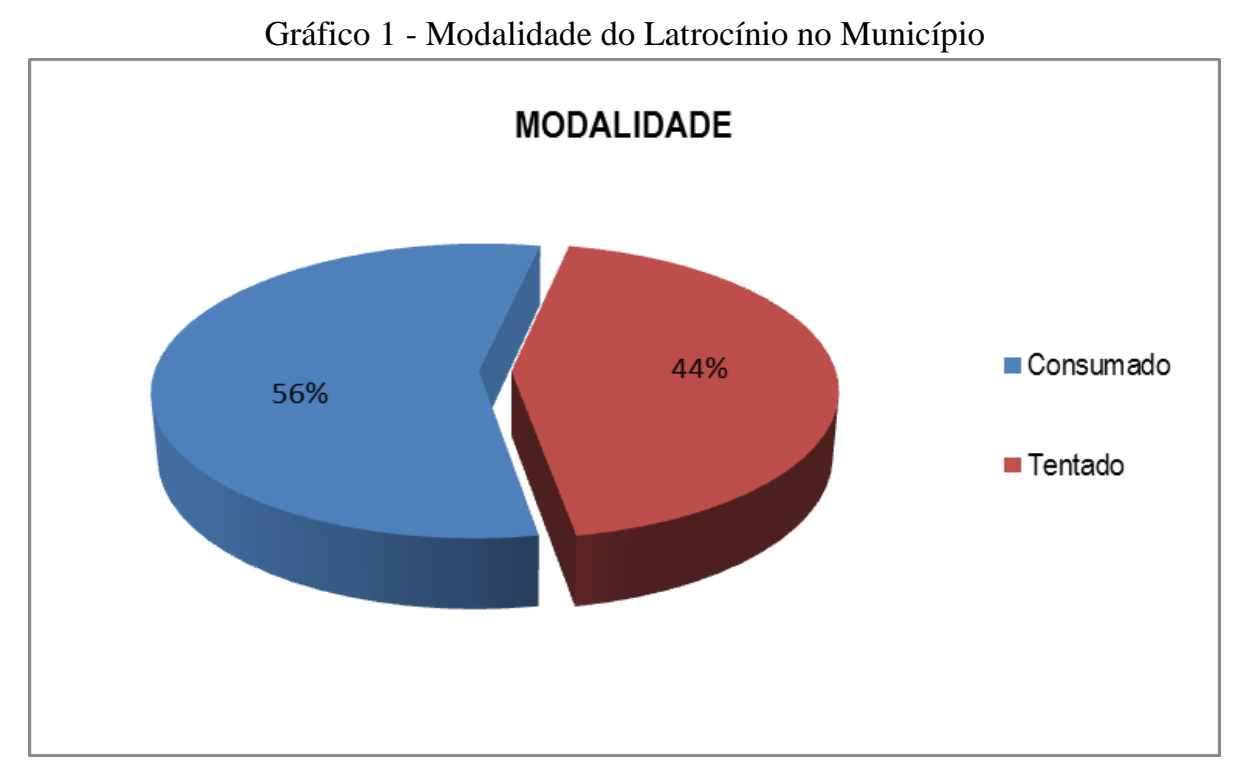

Fonte: Elaborado pela autora, 2016.

Conforme o levantamento das informações o parâmetro do delito no Munícipio foi de $56 \%$ na modalidade consumada e $44 \%$ na forma tentada.

Em relação à autoria, foram encontrados 34 autores do sexo masculino e apenas um do sexo feminino com participação efetiva. Por outro lado, a realidade do delito no Município demonstrou que há efetivamente o envolvimento de menores, e de acordo com a análise aos autos essa atuação foi essencial em alguns casos para a consumação do crime. Logo, constata- 


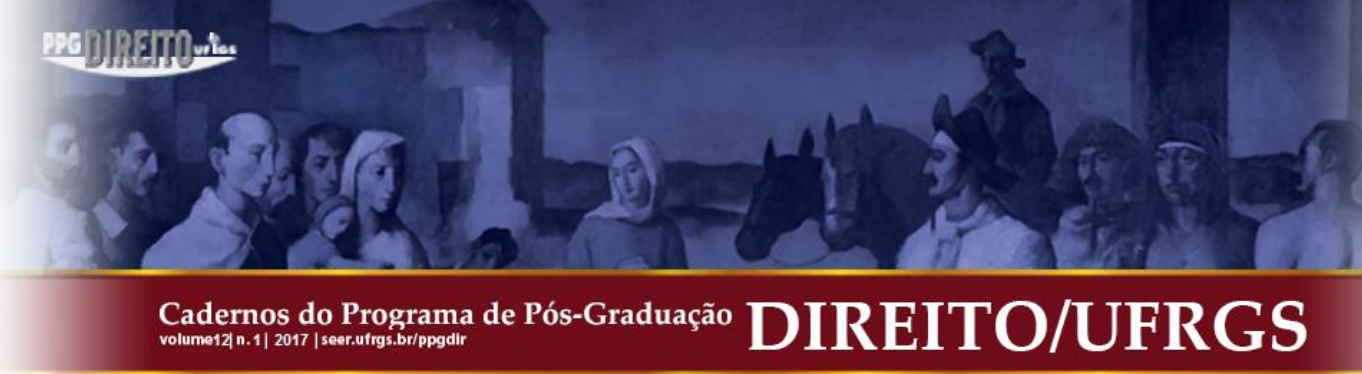

se que dos 25 delitos ocorridos no período estudado, em 07 deles houve a participação de menores, correspondendo a $28 \%$ do total.

Ainda, em relação à autoria, observa-se que, na maioria dos casos, os autores fizeram o uso de arma de fogo para atingir o resultado, ou seja, a intimidação e subtração do bem patrimonial desejado. Igualmente, verifica-se que alguns autores fizeram o uso de arma branca (na presente pesquisa descrita como faca e facão).

Desta maneira, do montante de 25 processos analisados, identifica-se que em $72 \%$ dos casos os autores fizeram o uso de arma de fogo para cometer o delito e em $24 \%$ dos casos fizeram o uso de arma branca, o que em números corresponde a 18 casos com o uso de arma de fogo e 06 casos com arma branca.

Esta informação resta demonstrada abaixo:

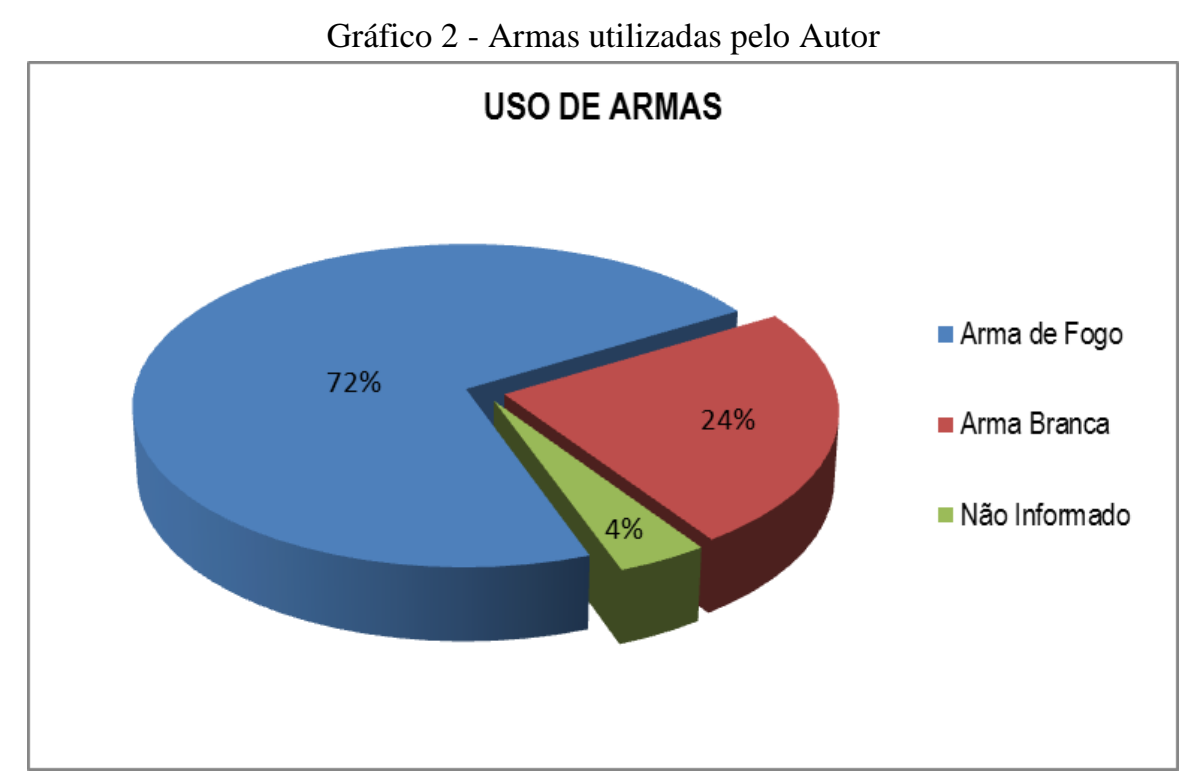

Fonte: Elaborado pela autora, $2016^{22}$.

Com essa relação estabelecida, obteve-se a informação sobre a proporção de vítimas fatais. Quando os autores fizeram o uso de arma de fogo esta porcentagem chegou a 50\%, já quando a arma branca foi utilizada o número de vítimas aumentou consideravelmente chegando a $83 \%$ de vítimas fatais. Verificando os autos não há indicação, na maioria dos casos, da procedência das armas de fogo, mas acredita-se que estas foram obtidas por meios

\footnotetext{
${ }^{22}$ A porção de $4 \%$ corresponde ao processo que não está cadastrado no sistema Themis. Assim, em razão do fato ter ocorrido antes da informatização do Judiciário, não foi possível verificar o tipo de arma utilizada pelo autor.
} 


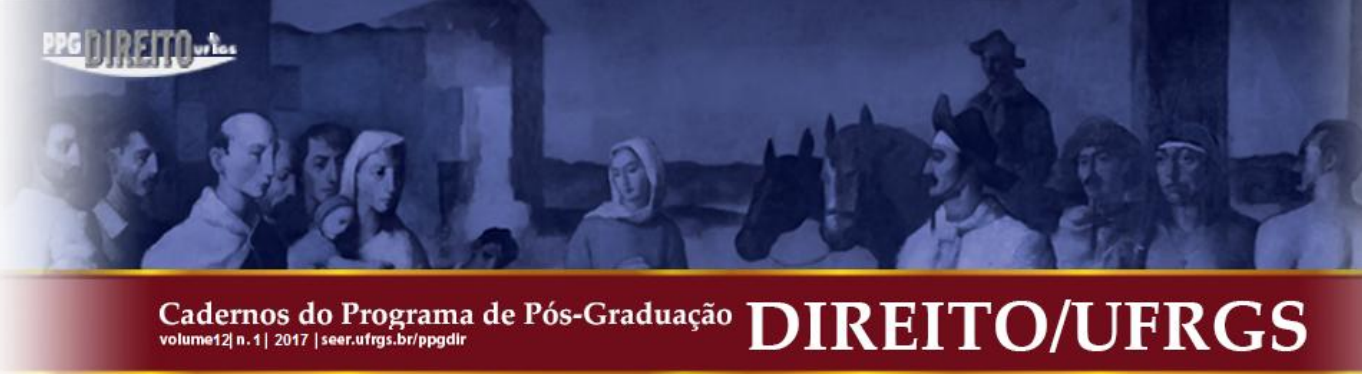

ilegais. Essa circulação de armas estabelece na sociedade um temor em relação à segurança e, pode ainda, contribuir indiretamente para o crescimento da criminalidade.

Outra informação relevante para esta pesquisa foi em relação à idade que os autores possuíam quando cometeram os delitos.

Conforme o gráfico abaixo:

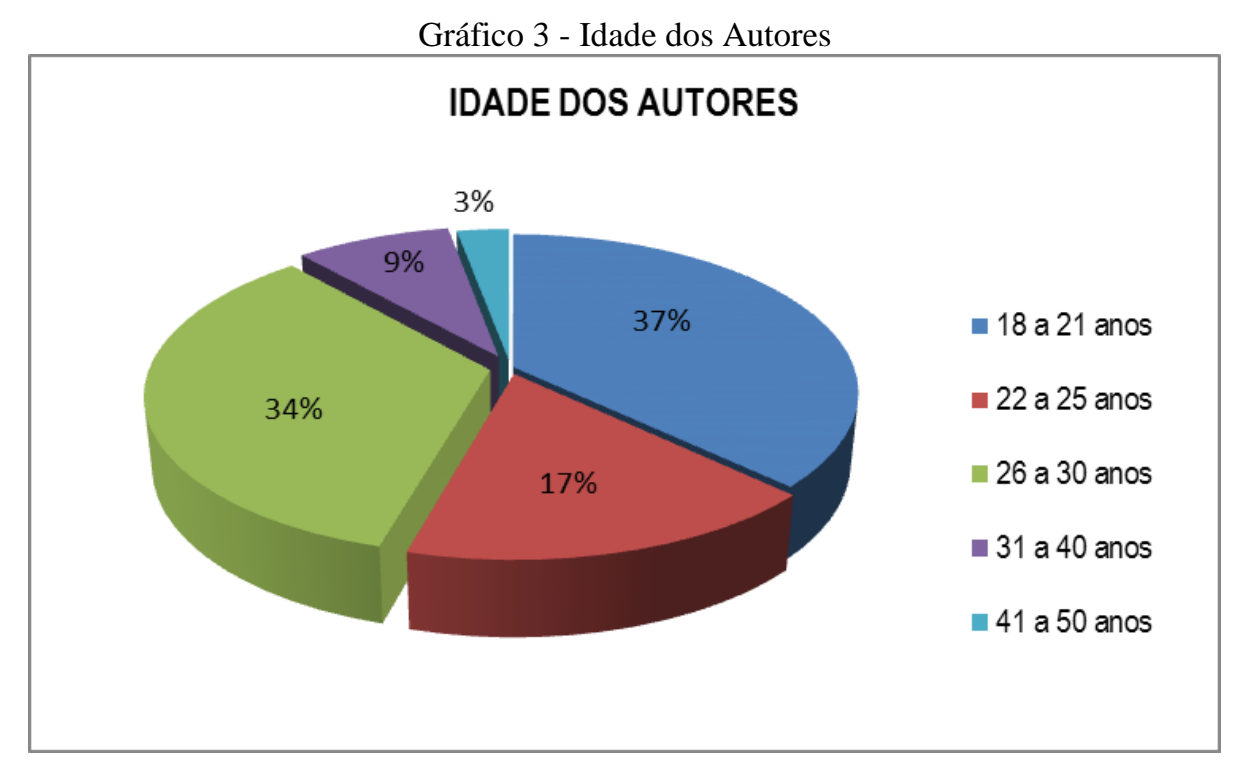

Fonte: Elaborado pela autora, 2016.

Em relação à idade, percebe-se que há uma fragmentação muito próxima entre duas faixas etárias. Deste modo, constatou-se que na época do fato, 13 autores possuíam entre 18 e 21 anos de idade, 12 autores entre 26 e 30 anos, 06 autores entre 22 e 25 anos, 03 autores entre 31 e 40 anos e somente um autor possuía a idade entre 41 e 50 anos.

No que diz respeito à educação, o gráfico demonstra que 14 autores possuem o $1^{\circ}$ grau incompleto, 05 possuem o $1^{\circ}$ grau completo, 03 possuem o $2^{\circ}$ grau incompleto, 01 concluiu o $2^{\circ}$ grau, 12 não informaram a escolaridade.

Embora não exista um padrão para o cometimento do delito, tão pouco para as características intelectuais dos autores, nota-se que uma grande porção apresenta o $1^{\mathrm{o}}$ grau incompleto. Ainda, verifica-se que há um índice muito baixo de autores com o $2^{\circ}$ grau completo e a total ausência de autores com nível superior. 
Estes dados restam demonstrados conforme o gráfico abaixo:

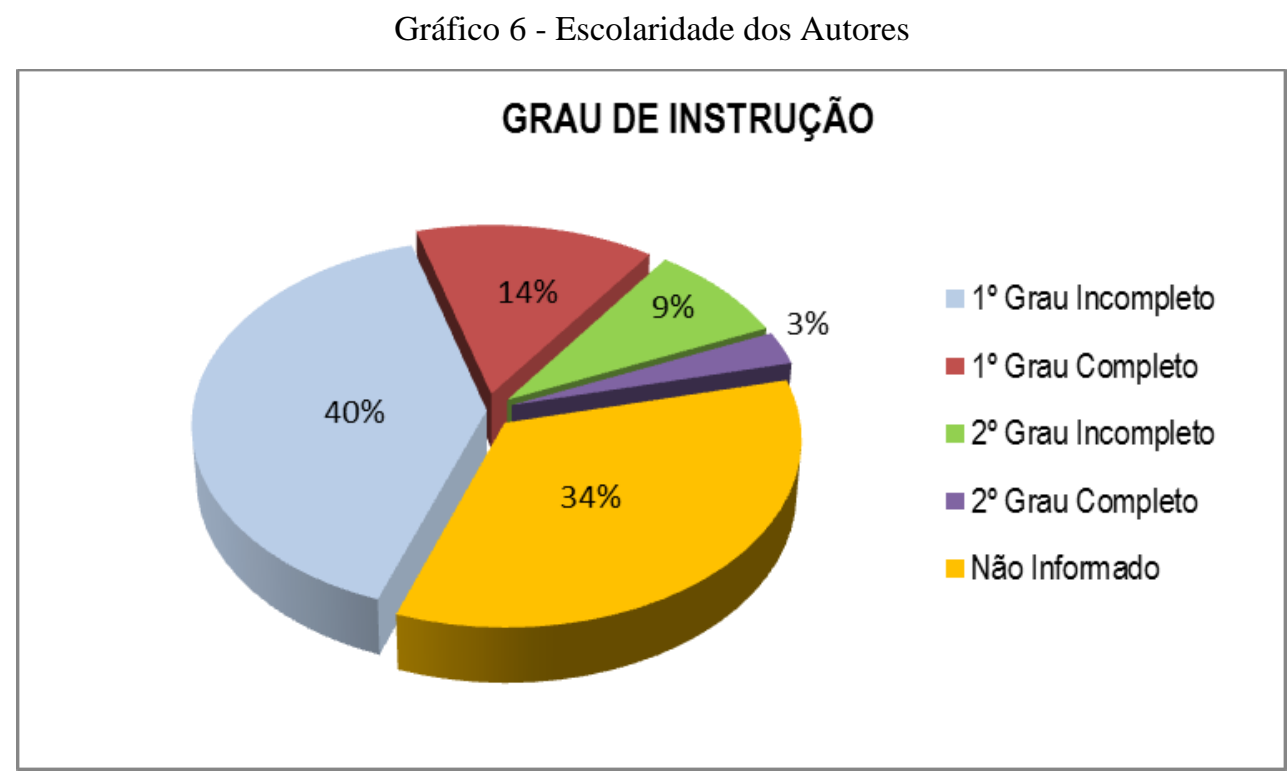

Fonte: Elaborado pela autora, 2016.

Percebe-se também, que a porção correspondente à escolaridade não informada, pode mascarar a realidade do delito. Assim, para evitar que esses dados ficassem ocultos retirou-se do total da amostra o percentual de $34 \%$ redefinindo este cenário. Com a tabulação dos dados restantes obteve-se uma nova estimativa, e consequentemente, novos parâmetros.

Esta nova exposição resta demonstrada abaixo:

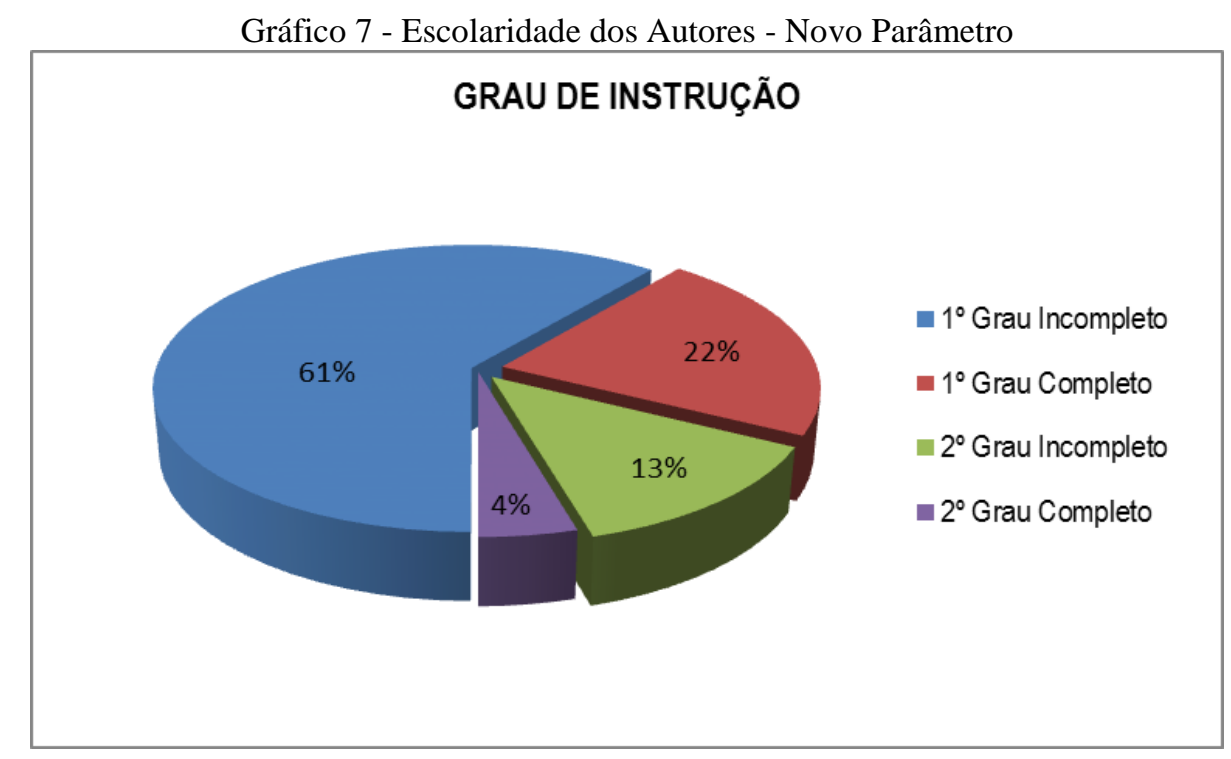

Fonte: Elaborado pela autora, 2016. 


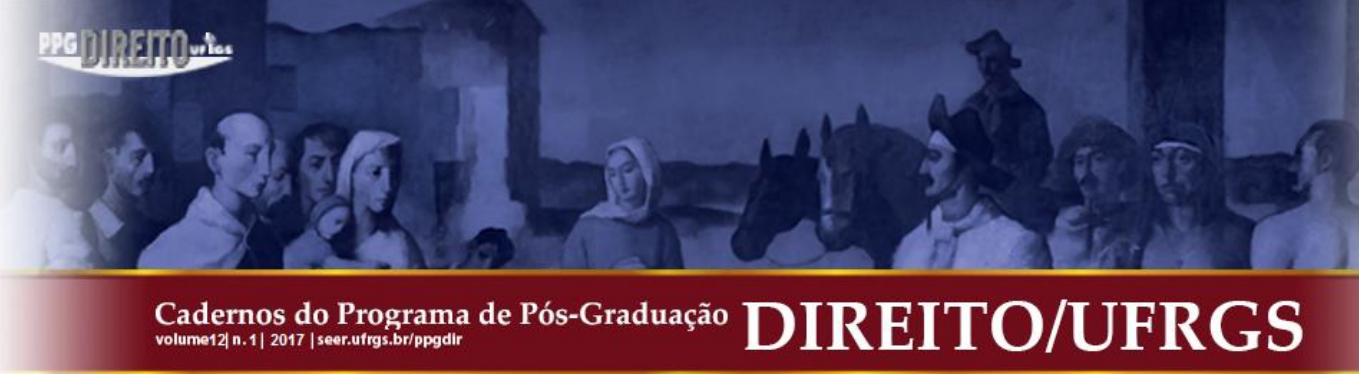

No que diz respeito à profissão, averiguou-se que apenas $9 \%$ dos autores exerciam atividades intelectuais, provavelmente, pelo próprio grau de instrução que estes apresentavam. Em contrapartida, o trabalho braçal abrange a maioria dos pesquisados e de certa forma poderia ser um pressuposto para o cometimento do delito. Talvez as atitudes dos autores estejam baseadas na própria realidade vivida por eles em meio a sociedade, uma vez que a vulnerabilidade social, a baixa escolaridade, à falta de acesso a melhores empregos e as restrições econômicas, cooperariam para o desencadeamento de condutas atípicas.

Conforme a Tabela demonstrada abaixo:

Tabela 1 - Profissões dos Autores

\begin{tabular}{l|c}
\multicolumn{1}{c}{ Profissões } & Quantidade de Autores \\
\hline Açougueiro & 2 \\
Auxiliar Administrativo & 1 \\
Auxiliar de Depósito & 1 \\
Auxiliar de Produção & 1 \\
Ajudante & 1 \\
Ajudante de Pedreiro & 3 \\
Carpinteiro & 1 \\
Cinegrafista & 1 \\
Comerciário & 1 \\
Cortador de Pedreira & 1 \\
Desempregado & 1 \\
Eletricista & 1 \\
Não informado & 13 \\
Pedreiro & 3 \\
Sem profissão & 1 \\
Servente de Obras & 2 \\
Serviços Gerais & 1 \\
Total & Fonte: Elaborada pela autora, 2016 \\
\hline
\end{tabular}

Assim, na época dos fatos, a ocupação profissional dos autores correspondia ao percentual de $9 \%$ para aqueles que desenvolviam atividades intelectuais e $48 \%$ para os que desenvolviam algum tipo de atividade braçal. Resta ainda a informação de que $03 \%$ dos autores estavam desempregados, $03 \%$ dos não possuíam profissão definida e $37 \%$ dos autores não indicaram a profissão nos autos.

\footnotetext{
${ }^{23}$ Estas informações partem da análise de todos os processos, inclusive os que não foram encontrados no arquivo judicial. Para esses processos utilizou-se a busca dos dados pelo sistema Themis do Judiciário.
} 


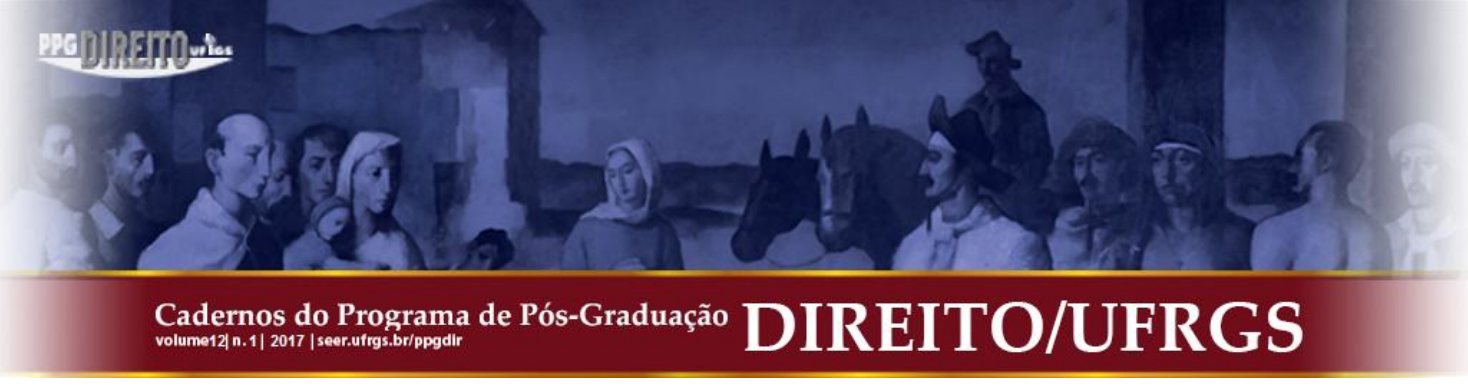

Em análise acerca das condutas dos agentes no cometimento do delito, através dos dados colhidos em pesquisa realizada nos processos pertencentes ao acervo do Tribunal de Justiça do Estado do Rio Grande do Sul, foi possível produzir as seguintes informações:

Tabela 1- Informações Quanto À Execução Do Delito

\begin{tabular}{|c|c|c|c|c|c|}
\hline \multicolumn{2}{|c|}{$\begin{array}{c}\text { QUESTÃO VIOLÊNCIA } \\
\text { A violência exercida pelo autor } \\
\text { antecede ou sucede a posse do } \\
\text { bem? }\end{array}$} & \multicolumn{2}{|c|}{$\begin{array}{c}\text { QUESTÃO REAÇÃO } \\
\text { A(s) vítima(s) reagiu(ram) ao } \\
\text { roubo? }\end{array}$} & \multicolumn{2}{|c|}{$\begin{array}{c}\text { QUESTÃO SUBTRAÇÃO } \\
\text { Houve subtração do bem } \\
\text { patrimonial? }\end{array}$} \\
\hline $\begin{array}{l}\text { Antes da } \\
\text { Posse }\end{array}$ & $\begin{array}{l}\text { Depois da } \\
\text { Posse }\end{array}$ & Sim & Não & Sim & Não \\
\hline 17 & 03 & 15 & 05 & 07 & 13 \\
\hline
\end{tabular}

Observou-se, conforme a Tabela, que na questão referente à violência, a agressão exercida pelo autor no cometimento do delito antecede a subtração do bem patrimonial em 17 dos processos analisados e em 03 processos essa violência sucede a subtração do bem. $\mathrm{Na}$ questão reação, observa-se que houve algum tipo de reação em 15 processos analisados e em 05 processos não foram detectadas reações por parte da(s) vítima(s). Por fim, na questão subtração, observa-se que em 07 processos houve a subtração do bem patrimonial e em 13 processos não houve a efetivação da subtração ao bem patrimonial.

Cabe ainda mencionar, que os dados levantados nesta Tabela partem da totalidade de 20 processos (porção de processos que possuíam informações relevantes para essa tabulação) além de um processo que foi analisado separadamente uma vez que apresentou 03 fatos distintos que ocorreram no intervalo de uma hora: no $1^{\circ}$ fato houve a subtração do bem, a violência exercida pelo autor foi posterior à posse do bem subtraído e não houve reação da(s) vítima(s), no $2^{\circ}$ e $3^{\circ}$ fato houve a subtração do bem, a violência foi exercida antes da subtração e não houve reação da vítima.

\section{A EXECUÇÃO PENAL E A SITUAÇÃO DOS AUTORES}

De acordo com a Lei de Execução Penal (LEP) $)^{24}$, após o trânsito em julgado de sentença condenatória será confeccionado um novo processo. Trata-se de uma nova relação jurídica, administrativa e jurisdicional destinada ao efetivo controle da pena onde,

24 BRASIL. Lei 7.210 de 11 de julho de 1984. Institui a Lei de Execução Penal. Disponível em: <http://www.planalto.gov.br/ccivil_03/LEIS/L7210.htm.>. Acesso em: 01 set. 2015. 


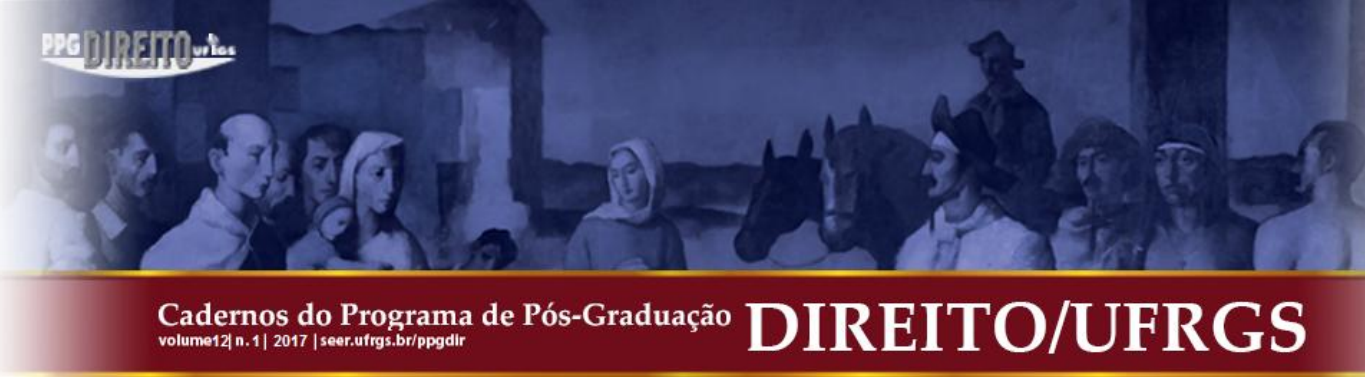

Em relação às faltas disciplinares graves, deve-se observar a disposição da $\mathrm{LEP}^{27}$ visto que podem ser adotadas medidas que alterem a execução da pena. Desta forma, quando o preso desrespeita alguma norma (classificada como falta grave) instaura-se um Processo Administrativo Disciplinar (PAD) para averiguação das possíveis infrações cometidas assegurando ao preso o direito ao contraditório e a ampla defesa.

Para que fosse possível examinar a continuidade ou não da violência no ambiente prisional, analisou-se individualmente cada Processo de Execução (PEC) ${ }^{28}$ a fim de averiguar se, do rol de autores selecionados, houve a prática de alguma infração disciplinar.

Os dados obtidos partem da totalidade de 30 apenados, visto que conforme demonstrado no gráfico 4, um apenado ainda não iniciou o cumprimento da pena, dois foram a óbito e dois cumpriram a pena sem nenhuma ocorrência disciplinar.

Logo, o número de apenados que tiveram alguma falta disciplinar no ambiente prisional resta demonstrado:

Gráfico 5 - Cometimento de Infrações Disciplinares

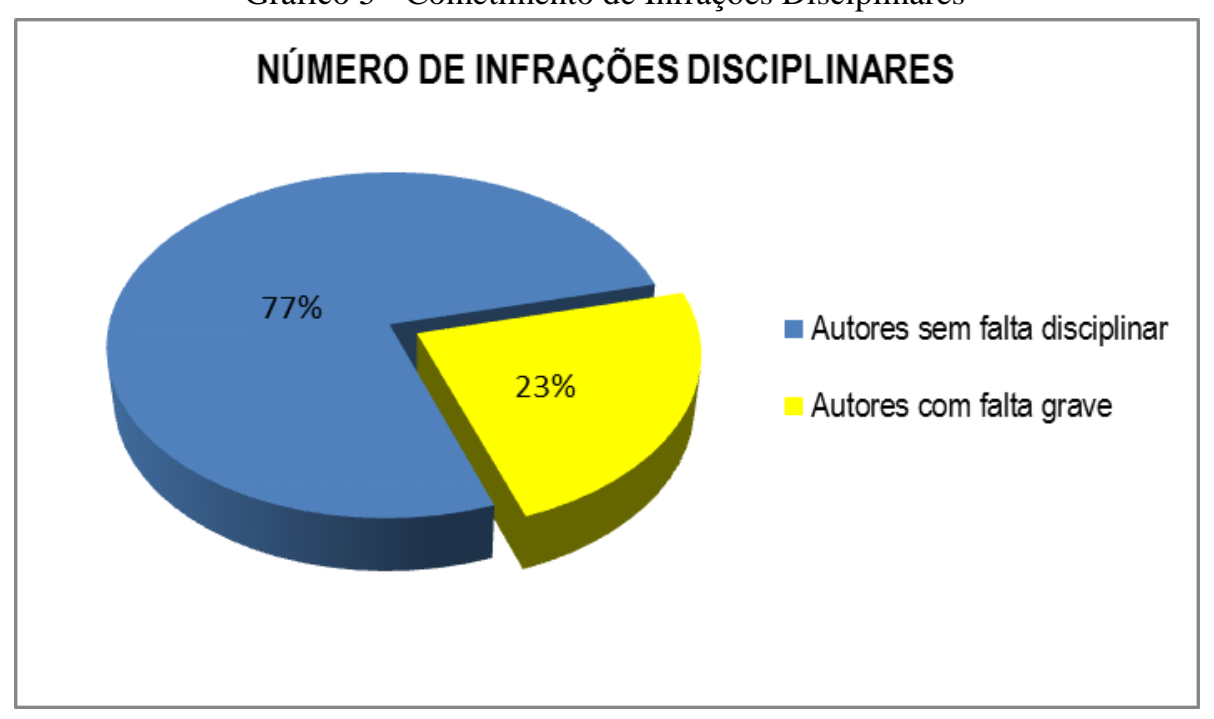

Fonte: Elaborado pela autora, 2016

Constata-se que do total de 30 apenados, 23 não cometeram nenhum tipo de infração disciplinar e 07 apenados cometeram infrações definidas pela legislação como falta disciplinar grave.

\footnotetext{
${ }^{27}$ As condutas estão descritas no artigo 50 da lei.

${ }^{28}$ O levantamento dos Processos Administrativos foi feito através da pasta da VEC, disponível no sistema Themis do Judiciário.
} 


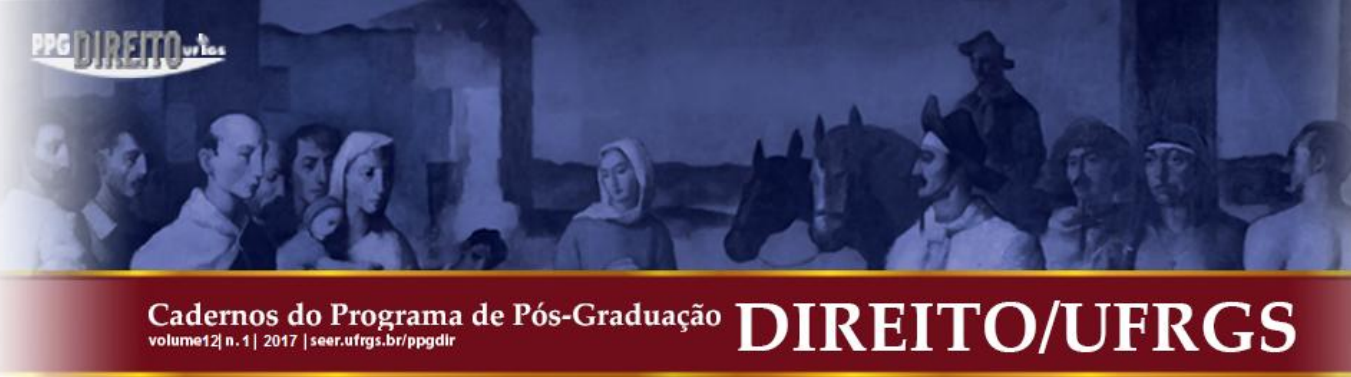

A tabela abaixo demonstra quais as condutas praticadas:

\begin{tabular}{c|c|c}
\hline \multicolumn{2}{c}{ Tabela - Processos Administrativos Disciplinares } \\
\hline $\mathbf{N}^{\mathbf{o}}$ de Infrações & Conduta & $\begin{array}{c}\text { Vara de } \\
\text { Execução (VEC) }\end{array}$ \\
\hline Uma & Fuga & Porto Alegre \\
Duas & $\begin{array}{c}\text { Desacato ao servidor e participação de movimento para } \\
\text { subverter a ordem ou a disciplina }\end{array}$ & Osório \\
Uma & Fuga & Osório \\
Uma & Fuga & Porto Alegre \\
Uma & Participação de movimento para subverter a ordem ou & Porto Alegre \\
Duas & a disciplina & Ijuí \\
Uma & Posse de celular & Porto Alegre \\
\hline
\end{tabular}

Fonte: Elaborado pela autora, 2016.

Com o rastreamento das informações, verificou-se que embora haja a existência de infrações disciplinares no ambiente prisional, nenhum dos delitos apreciados são condizentes com a questão da violência ou com a continuidade da mesma. Analisando os processos administrativos percebe-se que nas condutas de fuga os apenados estavam cumprindo pena em regime semiaberto, enquanto que, nas condutas de desacato ao servidor, subversão da ordem e disciplina e posse de celular os apenados cumpriam a pena em regime fechado.

De acordo com as informações obtidas o resultado é que não foi verificado nenhum tipo de conduta que demonstre a continuidade da violência, ou seja, não há o seguimento de atitudes violentas dentro do ambiente prisional para os autores analisados. Discutir sobre violência e delimitar seus possíveis motivos requer uma reflexão mais abrangente já que as circunstâncias que envolvem o referente delito são infinitamente difusas.

\section{CONSIDERAÇÕES FINAIS}

Uma das constatações perceptíveis foi que, em muitos casos, os autores já conheciam a rotina de suas vítimas e aproveitaram-se dessa confiança para atingir seu objetivo. Em contrapartida, observa-se também que alguns autores desfrutaram das oportunidades mais identificadas com o cometimento do crime de roubo (desatenção, ostentação de bens, etc). Em relação à forma de agir do autor percebeu-se uma gama de informações diretamente vinculadas as ações que desencadearam a violência. Primeiramente, constatou-se que o poder de intimidação que o autor executa sobre suas vítimas ocorre, na maioria dois casos, pelo uso 


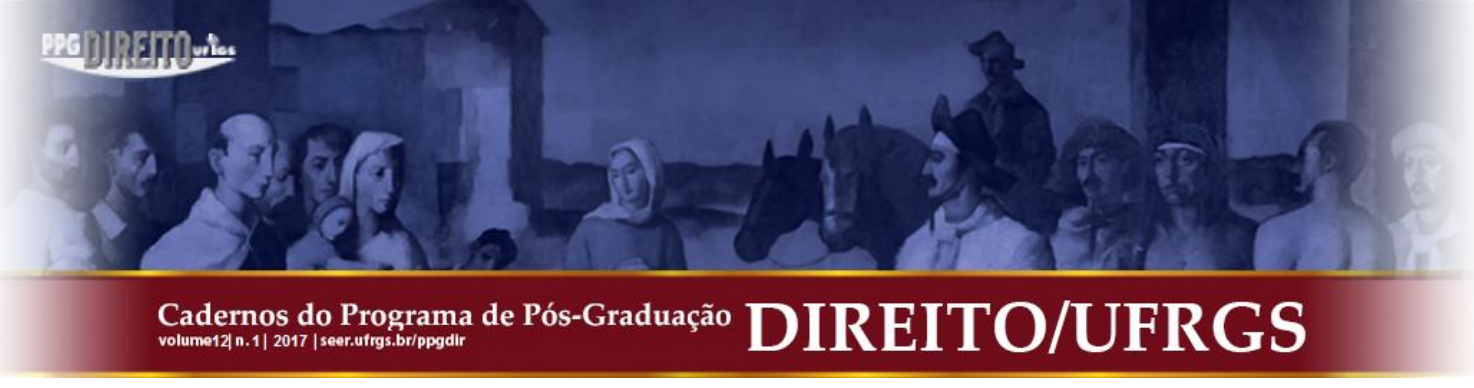

de arma de fogo, que pode desencadear no ofendido a reação ao delito no intuito de tentar salvar seu patrimônio ou defender sua integridade física.

No tocante a obtenção da posse, a reação do ofendido e a subtração do bem patrimonial constatou-se que, na maioria dos casos, a reação das vítimas desencadeou no agente o uso da violência, contudo não há como afirmar que essa reação tenha estimulado o autor a conter a vítima, pois também se observou a ocorrência de atitudes violentas sem aparentemente nenhuma reação. Ainda em relação à violência, percebeu-se que em muitos casos a agressão exercida pelo autor ocorreu posteriormente à subtração do bem, não sendo caracterizada como necessária para garantir a posse ou a manutenção do objeto.

Em relação à obtenção de lucro, constatou-se que em muitos casos as vítimas não tinham sob seu poder bens que representassem um grande valor patrimonial, pelo contrário, o que se vislumbrou foram autores inseridos em uma classe social inferior subtraindo pessoas que faziam parte da mesma classe.

Em relação à execução penal desses autores, observou-se que, ainda que tenham utilizado de extrema violência ao cometer o roubo, estas condutas não foram reiteradas no ambiente prisional. Inicialmente pode-se questionar porque rastrear tais condições já que não existem bens patrimoniais disponíveis para a subtração naquele ambiente. Entretanto, como mencionado, muitos casos fogem do contexto da subtração e, por isso, podem estar incluídos no cenário do cárcere como, por exemplo, a posse e manutenção de entorpecentes, as discussões, a conquista de espaços, a tentativa de afirmação de poder entre outros aspectos que efetivamente podem desencadear, nesse ambiente hostil, condutas violentas.

Ainda, restou comprovado que parte dos latrocínios ocorreram pelo desejo da apropriação e, nesse ambiente, inclui-se a obtenção de lucro para os fins mais variados possíveis. Todavia, comprovou-se também, que em alguns casos, há uma concretização da violência sem ligação aparente com a finalidade do crime, ou seja, sem a subtração, a posse e a manutenção do bem, e ao mesmo tempo sem uma explicação plausível para o cometimento das ações.

A produção de dados acerca da violência é importante pela coleta de informações que podem ser utilizadas por pesquisadores em momentos diversos, mas não supre a necessidade da reflexão sobre os dados e a importância da discussão teórica, muitas vezes subvalorizada em relação aos trabalhos quantitativos. Neste caso específico, há o risco sempre presente da patologização dos autores e do esquecimento das consequências usuais de políticas 
conservadoras de segurança pública. Afora a tradicional limitação operativa das instituições policiais, a cultura do medo do outro acentua a desproporção entre a imensidão do programa que discursivamente é recomendado às agências de criminalização secundária e sua capacidade efetiva: Não querendo corroborar a imagem de incompetência que a sociedade lhe atribui, as agências de criminalização optam pela seleção criminalizante do mais vulnerável, também para se fortalecer enquanto instituição, demonstrando efetividade ${ }^{29}$. A extensa existência das polícias nessa conjuntura de impotência e os imperativos constantes de rotulações em um país rigidamente hierarquizado estimulam a reiteração ritual da criminalização como medida tranquilizadora, também condicionada pelo poder de outras agências, como as de comunicação social. A seletividade é ainda mais excessiva em sociedades estratificadas como a brasileira, com maior concentração de riqueza e insuficientes possibilidades de mobilização vertical, o que se ajusta insidiosamente com a atuação violenta das agências de criminalização secundária.

\footnotetext{
Existe, geralmente, uma distorção na percepção da população sobre criminosos e criminalidade, causada, entre outros fatores, pela desigualdade social; pelo preconceito; pela ênfase da imprensa em certos tipos de crimes de interesse jornalístico; pelo contato com programas televisivos sobre o tema, ou ainda pela exploração política do tema da segurança pública. A questão fica mais clara quando se observa não só a magnitude, mas também o "sentido" das distorções. Não é casual que os grupos de status negativamente privilegiados - negros, migrantes, desempregados, viciados - tenham sua participação nos crimes, invariavelmente, superestimada $^{30}$.
}

A rotulação generalista dos autores de crimes violentos resulta no fortalecimento das atuações repressivas com tons racistas e classistas, tendo em vista a impossibilidade de fiscalização homogênea pelo aparato diminuto das agências em relação aos delitos e, também, pelos devaneios proféticos acerca da possibilidade de identificar previamente certo grupo de pessoas que estariam na iminência de cometer um delito futuro: a penalidade passa a ser um controle, não tanto sobre se o que fizeram os indivíduos está em conformidade ou não com a lei, mas ao nível do que podem fazer, do que são capazes de fazer, do que estão na iminência de fazer. Trata-se de uma virtualidade que projeta uma penalidade que procura punir/corrigir o próprio perigo e que proporcionou a grande e escandalosa noção de periculosidade: A noção de periculosidade significa que o indivíduo deve ser considerado pela sociedade ao nível de

\footnotetext{
${ }^{29}$ ZAFFARONI, E. Raul; BATISTA,Nilo; ALAGIA, Alejandro; SLOKAR, Alejandro. Direito Penal Brasileiro: Teoria Geral do Direito Penal. 2. ed. Rio de Janeiro: Revan, 2003, p. 44.

${ }^{30}$ PASTANA, Débora Regina. Cultura do Medo: Reflexões sobre violência criminal, controle social e cidadania no Brasil. São Paulo: Método, 2003, p. 77.
} 


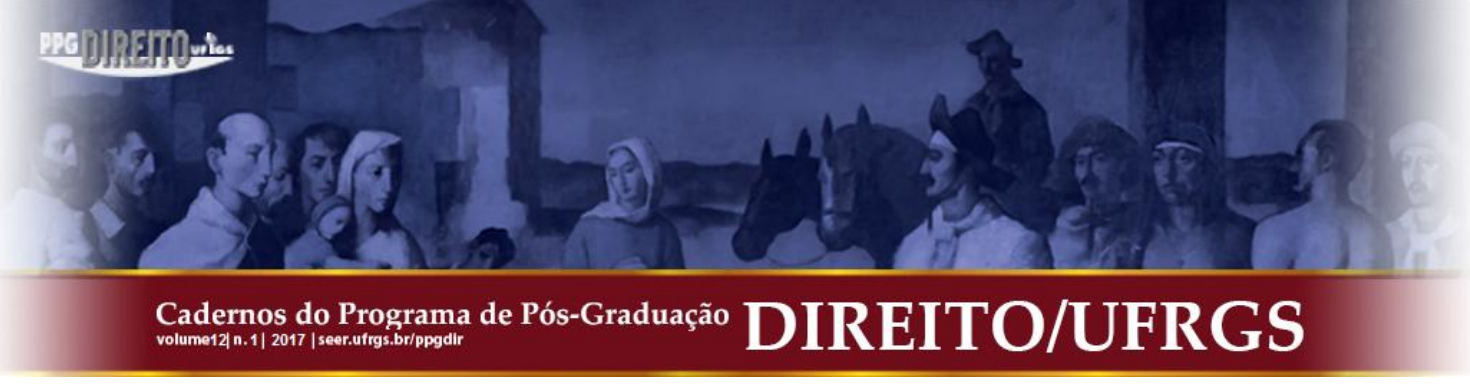

suas virtualidades e não ao nível de seus atos; não ao nível das infrações efetivas a uma lei efetiva, mas das virtualidades de comportamento que elas representam ${ }^{31}$.

\begin{abstract}
Importante recordar que a medicina não atropelou o direito penal, foi antes, ao lado dos mecanismos de punição e dos sentidos que lhes foi atribuído que a medicina mental penetrou na penalidade. Punir tornou-se, dentre todas as novas técnicas de controle e transformação dos indivíduos, um conjunto de procedimentos orquestrados para modificar os infratores: $\mathrm{O}$ exemplo aterrorizante dos suplícios ou a exclusão pelo banimento não podiam mais bastar em uma sociedade na qual o exercício do poder implicava uma tecnologia racional dos indivíduos. As formas de punição, às quais aderem todos os reformadores do final do século XVIII e todos os legisladores do início do século XIX (ou seja, o aprisionamento, o trabalho obrigatório, a vigilância constante, o isolamento parcial ou total, a reforma moral) implicam que a punição aja menos sobre o crime do que sobre o próprio criminoso e seus instintos, motivações e subjetividade ${ }^{32}$.
\end{abstract}

No caso dos relatos expostos, em que a motivação utilitária muitas vezes não esteve tão destacada, tendo o motivo do crime se tornado o motivo de punir, como punir quando o crime não tem motivo? Como atribuir sentido à punição quando não há motivo para o cometimento do crime? A hipótese Foucaltiana coloca nesse paradoxo as condições de possibilidade da inclusão da medicina mental no controle punitivo. Os magistrados, buscando saída para o paradoxo em que estavam encerrados, aceitam de bom grado o conjunto de conceitos levantados pelas noções médicas, sobretudo a integração do crime à conduta global do sujeito. Quanto mais essa integração aparecer, mais o sujeito aparecerá como punível. Quanto menos ela for evidente, mais o ato parecerá irromper no sujeito como mecanismo súbito e incontrolável e menos o responsável aparecerá como punível. A justiça, então, aceitará se desincumbir dele por ser louco, confiando-o à prisão psiquiátrica. Assim, a intervenção da medicina mental na instituição penal e nos seus discursos legitimantes torna-se conseqüência tanto da concepção da medicina como higiene pública como do funcionamento da punição legal como técnica de transformação individual ${ }^{33}$.

Que justiça e medicina mental disputem o ato de Riviére levanta primeiramente um problema de classificação em referência aos dois núcleos de saber: culpado ou louco. Atrás deste confronto teórico, esboça-se igualmente uma concorrência entre os agentes que defendem seus lugares na divisão de trabalho social: a que tipo de especialistas confiar este homem, e qual será sua "carreira", em função do veredicto ou do diagnóstico? Mas assiste-se ainda, em terceiro lugar, através da unanimidade da psiquiatria nascente, a tentativa de ganhar um espaço de intervenção entre o

\footnotetext{
${ }^{31}$ FOUCAULT, Michel. A Verdade e as Formas Jurídicas. Tradução de Roberto Machado e outros. Rio de Janeiro: Nau Editora, 2005, p. 85.

${ }^{32}$ FOUCAULT, Michel. op. cit., p. 12.

${ }^{33}$ FOUCAULT, Michel. op. cit., p. 14. 
depois e o antes, a repressão consecutiva e a ação preventiva, no qual o futuro da medicina mental vai se desdobrar. Num sentido, o aparelho judiciário se põe em marcha quando os jogos são feitos. Do lado da medicina mental, procura-se um novo dispositivo: uma intervenção que não seria condenada a chegar sempre muito tarde, porque ela estaria fundamentada sobre um saber capaz de antecipar a possibilidade de uma conduta delituosa antes mesmo que ela se produza ${ }^{34}$.

A prevenção especial positiva coloca-se como alternativa ao retribucionismo irracional, pois parte do pressuposto de que a pena é um bem para quem a sofre. Se a pena é um bem, sua medida é aquela necessária para realizar a ideologia ressocializadora que for sustentada, ou seja, ilimitadamente. O Estado neste caso há de se tornar paternalista e causador de supostos benefícios biológicos-materialistas advindos de um argumento criminológico positivista ou correcionalista, sendo que mesmo que fossem contrariados todos os dados históricos e sociais que atestam sua ineficácia, tal concepção discursiva consistiria numa imposição de valores privada de ética e que desconhece a autonomia própria da pessoa $^{35}$.

Os indivíduos tidos como perigosos tornam-se portadores de elevados índices de probabilidade criminal, sendo em si mesmo risco de crime. A punição passa a ter finalidade de diminuir, na medida do possível, seja por eliminação, exclusão, restrições diversas ou medidas terapêuticas o risco de criminalidade representado pelos indivíduos perigosos. Nesta concepção, o livre arbítrio ou a escolha voluntária pelo mal já não está em questão, o indivíduo é criador de risco unicamente por sua existência. São criadas, assim, condições de possibilidade para outros questionamentos: Há indivíduos intrinsecamente perigosos? Como é possível reconhecê-los ${ }^{36}$ ?

O discurso científico da inferioridade bio-psico-antropológica não permitia duvidar da superioridade branca européia. Agora não mais o herege, mas o perverso; não mais o satânico, mas o selvagem. Este pensamento etiológico - modelo substancialista racista e totalitário - é desqualificado no período pós-guerra por suas consequiências políticas, e logo depois é retomado sob a feição humanizadora do movimento da Nova Defesa Social, visando identificar os sujeitos perigosos e reabilitá-los desde o enfoque médico-psiquiátrico: da ótica jurídica ao universo das ciências médicas. O advento da dogmática não logrou extirpar este discurso etiológico, apenas deslocou a Criminologia a um saber auxiliar na tipologia das enciclopédias penais. A defesa social repousa na substituição da pena retributiva pelo tratamento. Ao antecedente criminoso, a Criminologia apresenta a promessa de

\footnotetext{
${ }^{34}$ FOUCAULT, Michel. Eu, Pierre Riviére, que degolei minha mãe, minha irmã e meu irmão... Rio de Janeiro: Graal, 1977, p. 260.

${ }^{35}$ ZAFFARONI, E. Raul; BATISTA,Nilo; ALAGIA, Alejandro; SLOKAR, Alejandro.op. cit., p. 125.

${ }^{36}$ FOUCALT, Michel. Ditos \& Escritos V: Ética, sexualidade e política. Rio de Janeiro: Forense Universitária, 2004, p. 22.
} 


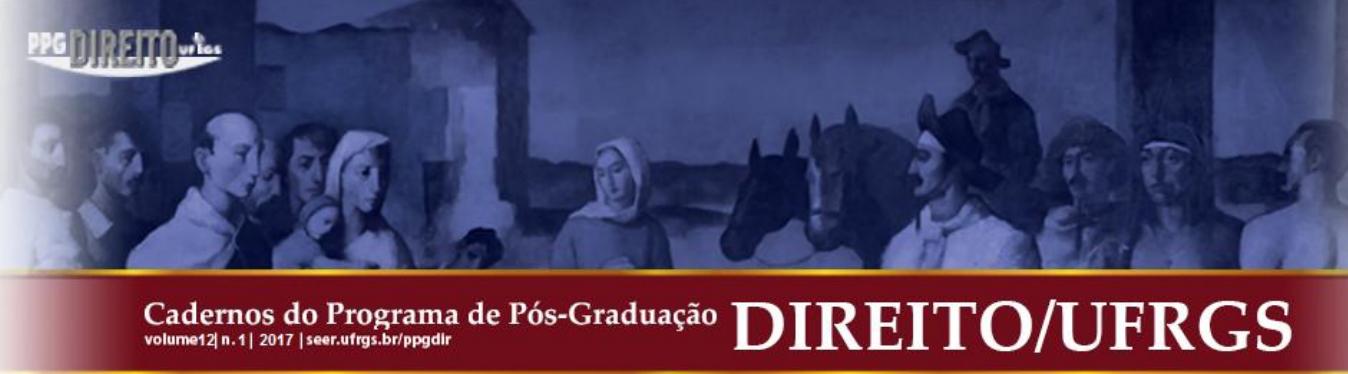

uma nova vida sob o mágico postulado da "recuperação". A ciência ocupada por
pensadores do direito e da política até meados do séc. XIX é invadida por uma série
de profissionais alheios ao mundo jurídico: médicos, psiquiatras, anatomistas $[. . .]^{37}$.

Michel Foucault expressa que os discursos legitimantes do sistema penal fizeram com que os juízes julgassem bem mais do que crimes, através de instrumentos extrajurídicos de justificação que ao mesmo tempo eram utilizados como escusa para punir arbitrariamente $^{38}$. Nesse contexto, é que entra em cena o psiquiatra como conselheiro de punição, cabendo-lhe dizer se o indivíduo é perigoso. A legitimação do saber jurídico, diante deste novo regime da verdade se dá desde o discurso clínico, isto é, a justiça criminal hoje em dia só se justifica por essa perpétua referência a outra coisa que não é ela mesma, por essa incessante reinscrição nos sistemas não jurídicos ${ }^{39}$ que obedece a uma lógica marcadamente maniqueísta $^{40}$. Por isso, a penalidade do século XIX torna-se forma de controle que não vincula a pena com o crime, mas com a projeção de perigo atribuída ao indivíduo selecionado. Virtualmente cria-se uma suposta relação entre a pena e a noção escandalosa de periculosidade:

\begin{abstract}
A noção de periculosidade significa que o indivíduo deve ser considerado pela sociedade ao nível de suas virtualidades e não ao nível de seus atos; não ao nível das infrações efetivas a uma lei efetiva, mas das virtualidades de comportamento que elas representam ${ }^{41}$.
\end{abstract}

O acréscimo nas taxas de criminalidade sustenta o receio público do crime e produz padrões complexos de comportamento de evitação. A área da cidade revela-se um mapa intrincado de zonas proibidas, de metrôs e parques a serem evitados, de estacionamentos que se podem atravessar a espaços públicos que devem ser utilizados com atenção ${ }^{42}$. Este temor, decorrente seja de imagens, palavras, alegorias ou mesmo de experiências concretas, sejam elas autênticas ou fantasiosas, colabora na desagregação social, na destruição das redes de

\footnotetext{
${ }^{37}$ CARVALHO, Salo. Pena e Garantias. 2. ed. Rio de janeiro: Lumen Juris, 2003, p. 70.

${ }^{38}$ FOUCAULT, Michel. Vigiar e Punir: Nascimento da Prisão. Tradução de Raquel Ramalhete. Petrópolis: Vozes, 1987, p. 22-23.

${ }^{39}$ FOUCAULT, Michel. op. cit., 1987, p. 23.

40 MAYORA, Marcelo; LINCK, José; PANDOLFO, Alexandre Costi; LUCHESE, Marcelo. Centauros no Central: Análise dos Preconceitos Morais no Imaginário dos Juristas. Revista de Estudos Criminais, Porto Alegre, v. 29, p. 115-128, 2008.

${ }^{41}$ FOUCAULT, Michel. A Verdade e as Formas Jurídicas. Tradução de Roberto Machado e outros. Rio de Janeiro: Nau Editora, 2005, p. 85.

42 YOUNG, Jock. A Sociedade Excludente: Exclusão Social, Criminalidade e Diferença na Modernidade Recente. Rio de Janeiro: Revan, 2002, p. 37
} 
política criminal, o atuarialismo considera que os conceitos econômicos básicos, como racionalidade, maximização, custos e benefícios, etc., são fundamentais para entender, explicar e combater de maneira efetiva a atividade criminal. As políticas neo-conservadoras de combate ao delito tem como principal objetivo a dissuasão do delinqüente, mediante a modificação do preço do delito, ou a sua pura e simples contenção. Se trata de encontrar políticas de otimização da relação custo benefício do combate ao crime, com o mínimo custo possível para o Estado ${ }^{48}$.

Colocar o aumento da criminalidade como um fator normal da sociedade contemporânea e alertar para a ineficácia do controle estatal como forma de resolver definitivamente as taxas de delinquência tornam-se argumentos cada vez mais recorrentes e estimulam novas medidas por parte das políticas de segurança pública ${ }^{49}$.

\begin{abstract}
As normas de ação decorrentes não se endereçam apenas aos organismos do Estado, endereçam-se às organizações, instituições e indivíduos da sociedade civil. As teorias dão por estabelecida a capacidade limitada do Estado. Os novos programas de ação procuram influenciar a conduta das vítimas potenciais, armar os alvos vulneráveis, melhorar a segurança em zonas perigosas e reestruturar as rotinas da vida cotidiana que têm por consequiência desagradável propiciar ocasiões para o crime. Essa criminologia expeditiva visa, de fato, modificar as rotinas cotidianas da vida social e econômica em direções que limitem a ocasião, redistribuam os custos e criem efeitos dissuasivos. Ela procura instaurar controles antes no seio do desdobramento da interação normal do que num plano superior, na forma de um comando soberano. Mas lá onde a idéia de repressão interna remetia ao domínio de si e à civilidade de humanos que participam de uma cena, recorrem-se hoje às tecnologias de segurança e supervisão ${ }^{50}$.
\end{abstract}

Ao contrário de um controle que busque apenas por fatos delituosos ou faça perguntas para desvelar uma subjetividade anormal e sua necessidade de correção, a contenção é dinâmica e o mecanismo de seletividade mais funcional, utilizando-se de signos semiidentitários, independentes de intenções institucionais ou projetivas. No Brasil, a difusão do medo legitima estratégias de neutralização e reitera o cerimonial da morte como espetáculo de lei e ordem $^{51}$. Tendo experimentado os benefícios da violência e da perseguição como solução para a crise em que vive, a sociedade busca meios para perpetuar a estabilidade por ela proporcionada, passando a ritualizar frequentemente o sacrifício.

Os países periféricos nunca adquiriram características relevantes de dispositivos criminais disciplinares, mantendo sempre a eliminação subjetiva e física que condena à morte

\footnotetext{
${ }^{48}$ AZEVEDO, Rodrigo Ghiringhelli de. Visões da Sociedade Punitiva: Elementos para uma Sociologia do Controle Penal. In: GAUER, Ruth M. Chittó (Org.). Sistema Penal e Violência. Rio de Janeiro: Lumen Juris, 2006, p. 59.

${ }^{49}$ GARLAND, David. As Contradições da Sociedade Punitiva. Revista de Sociologia e Política, Departamento de Ciências Sociais UFPR, 1999, p. 63.

${ }^{50}$ GARLAND, David. op. cit., p. 66.

${ }^{51}$ BATISTA, Vera Malaguti. O Medo na Cidade do Rio de Janeiro: Dois Tempos de uma História. Rio de Janeiro: Revan, 2003, p. 53.
} 
amplo setor periférico ${ }^{52}$. No Brasil, os signos de neutralização e contenção característicos das prisões periféricas foram vastamente fortalecidos por dois longos períodos autoritários, sustentando a edificação de uma estrutura repressiva de tamanha envergadura que, mesmo a democratização das mais importantes esferas institucionais, não conseguiu quebrar sua coesão, manifesta nos sequestros institucionais e nas burlas jurídicas ${ }^{53}$ :

\begin{abstract}
As características do avanço contra o tradicional direito penal liberal ou de garantias consistiriam na antecipação das barreiras de punição (até os atos preparatórios), na desproporção das conseqüências jurídicas (penas como medida de contenção sem proporção com a lesão realmente inferida), na marcada debilitação das garantias processuais e na identificação dos destinatários mediante um forte movimento para o direito penal de autor. Na doutrina jurídico-penal, pode-se distinguir o debilitamento do direito penal de garantias através da imputação jurídica conforme critérios que são independentes da causalidade; da minimização da ação em benefício da omissão, sem que interesse o que o agente realmente faça, a não ser o dever que tenha violado; da construção do dolo sobre a base do simples conhecimento (teoria do conhecimento), que lhe permite abarcar campos antes considerados próprios da negligência; da perda de conteúdo material do bem jurídico, com os conseqüentes processos de clonação que permitem uma nebulosa multiplicação de elos; do cancelamento da exigência de lesividade conforme à multiplicação de tipos de perigo sem perigo (perigo abstrato ou presumido); da lesão à legalidade mediante tipos confusos e vagos e a delegação de função legislativa penal, sob o pretexto das chamadas leis penais em branco, etc ${ }^{54}$.
\end{abstract}

A pesquisa, portanto, não pretendeu expor uma realidade de violência na expectativa de controle através de mecanismos cujo resultado recorrente é a reprodução de perversidades, mas uma série de questões ficaram abertas para trabalhos posteriores. Há falta de pesquisas específicas sobre execuções no Brasil contemporâneo, focadas nos autores. Os roubos combinados com torturas, sequestros ou execuções parecem exceder um pouco o conceito "criminalidade urbana violenta". Existiria relação entre o agravamento da situação prisional e o aparente aumento de intensidade da violência urbana? Há relação entre os discursos fascistas nas classes média/alta e o aparente aumento de intensidade da violência? Há relação entre a fetichização das moradias/automóveis e a presença de perversões nos modos de obtenção dos objetos por parte dos autores? Qual a relação entre a organização dos grupos e a violência? Aparentemente, quanto mais organizado, menos violento. É a organização (em si) ou o controle horizontal que possibilitam maior regulação ética?

\footnotetext{
${ }^{52}$ FREIRE, Christiane Russomano. A Violência do Sistema Penal Brasileiro Contemporâneo: O caso RDD. São Paulo: IBCCRIM, 2005, p. 113.

${ }^{53}$ FREIRE, Christiane Russomano. op. cit., p. 115.

${ }^{54}$ ZAFFARONI, E. Raul; BATISTA,Nilo; ALAGIA, Alejandro; SLOKAR, Alejandro. op. cit., p. 15. 


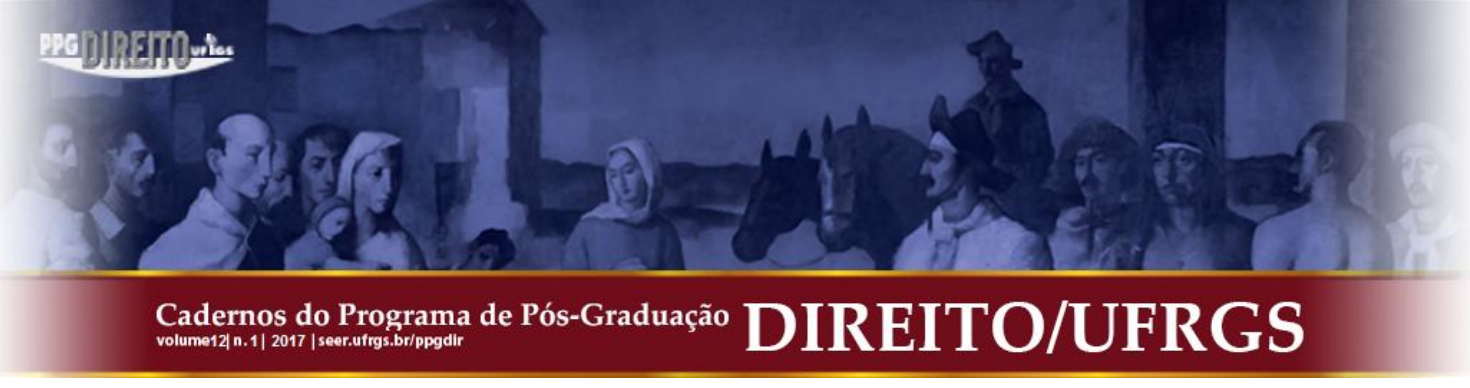

Poderia ser interessante pesquisar sobre os autores desses crimes para tentar construir algo sobre suas narrativas e trajetórias, evidentemente contendo a ânsia pela patologização ou despersonalização dos Sujeitos. Interessante problematizar, também, os casos de violência policial com nítidos tons de sadismo, como os que são observados (e filmados) em manifestações sociais e ações em periferias, corroborados não apenas com absolvição dos torturadores, mas inclusive com a condenação da vítima, demonstrando a cultura de violência em que ampla parcela populacional está inserida.

\section{REFERÊNCIAS}

ABRAMOVAY, Miriam. et al. Juventude, Violência e Vulnerabilidade Social na América Latina: Desafios para Políticas Públicas. UNESCO BRASIL. 2002. Disponível em <http://unesdoc.unesco.org/images/0012/001271/127138por.pdf >. Acesso em 23 abr.2016.

ANDRADE, Vera Regina Pereira de. A Ilusão de Segurança Jurídica. Do controle da violência à violência do controle penal. 2. ed. Porto Alegre. Livraria do Advogado, 2003.

Do Paradigma Etiológico ao Paradigma da Reação Social: mudança e permanência de paradigmas criminológicos na ciência e no senso comum. Estudos Jurídicos e Políticos, n. 30, Jun. 1995. Disponível em: <https://periodicos.ufsc.br/index.php/sequencia/article/view/15819>. Acesso em 23 abr.2016.

AZEVEDO, Rodrigo Ghiringhelli de. Visões da Sociedade Punitiva: Elementos para uma Sociologia do Controle Penal. In: GAUER, Ruth M. Chittó (Org.). Sistema Penal e Violência. Rio de Janeiro: Lumen Juris, 2006.

BAIERL, Luzia Fátima. Medo Social. São Paulo: Cortez, 2004.

BARATTA, Alessandro. Criminologia Crítica e Crítica do Direito Penal. Introdução à Sociologia do Direito Penal. 6. ed. Rio de Janeiro: Revan, 2011.

BARBOSA, Marcelo Fortes. Latrocínio. 1. ed. São Paulo. Malheiros. 1997.

BATISTA, Vera Malaguti. O Medo na Cidade do Rio de Janeiro: Dois Tempos de uma História. Rio de Janeiro: Revan, 2003.

BITENCOURT, Cezar Roberto. Tratado de Direito Penal. Parte Especial 3. 5. ed. São Paulo: Saraiva. 2009.

BRASIL. Código de Processo Penal Brasileiro. Decreto Lei ${ }^{\circ} 3.689$ de 03 de outubro de 1941. Disponível em: <http://www.planalto.gov.br/ccivil_03/DecretoLei/Del3689Compilado.htm>. Acesso em: 26 mar. de 2016. 
Código Penal Brasileiro. Decreto Lei no 2.848 de 07 de dezembro de 1940. Disponível em: <http://www.planalto.gov.br/ccivil_03/decreto-lei/Del2848compilado.htm>. Acesso em: 29 ago. 2015.

Constituição da República Federativa do Brasil de 1988. Disponível em: <http://www.planalto.gov.br/ccivil_03/constituicao/ConstituicaoCompilado.htm〉. Acesso em: 01 set. 2015.

. Lei 11.464, de 28 de março de 2007. Dá nova redação ao art. $2^{\circ}$ da Lei n ${ }^{0} 8.072$, de 25 de julho de 1990, que dispõe sobre os crimes hediondos, nos termos do inciso XLIII do art. $5^{\circ}$ da Constituição Federal. Disponível em: http://www.planalto.gov.br/ccivil_03/_ato20072010/2007/Lei/L11464.htm>. Acesso em 02 mai. 2016.

Lei 7.210 de 11 de julho de 1984. Institui a Lei de Execução Penal. Disponível em: <http://www.planalto.gov.br/ccivil_03/LEIS/L7210.htm.>.Acesso em: 01 set. 2015.

Lei 8.072 de 25 de julho de 1990. Dispõe sobre os Crimes Hediondos, nos termos do art. $5^{\circ}$, inciso XLIII, da Constituição Federal, e determina outras providências. Disponível em: <http://www.planalto.gov.br/CCIVIL_03/leis/L8072.htm> Acesso em: 31 ago. 2015.

. Supremo Tribunal Federal. Súmula 610. DJ de 31 de outubro de 1984. Disponível em: <http://www.stf.jus.br/portal/jurisprudencia/menuSumarioSumulas.asp?sumula=2562>. Acesso em: Acesso em 31 ago. 2015.

CAPEZ, Fernando. Curso de Direito Penal. Parte Especial. 8. ed. São Paulo: Saraiva. 2008.

CARVALHO, Luiz Penteado de. Furto, Roubo, Latrocínio. 3. ed. São Paulo: Editora Juruá: 1977.

CARVALHO, Salo. Pena e Garantias. 2. ed. Rio de janeiro: Lumen Juris, 2003.

COSTA, Álvaro Mayrink da. Criminologia. 4. ed. Rio de Janeiro: Forense. 2005.

DOTTI, René Ariel. Curso de Direito Penal. Parte Geral. 4. ed. São Paulo: Revista dos Tribunais, 2012.

FOUCALT, Michel. A Verdade e as Formas Jurídicas. Tradução de Roberto Machado e outros. Rio de Janeiro: Nau Editora, 2005.

Ditos \& Escritos V: Ética, sexualidade e política. Rio de Janeiro: Forense Universitária, 2004.

. Eu, Pierre Riviére, que degolei minha mãe, minha irmã e meu irmão... Rio de Janeiro: Graal, 1977. 
Vozes, 1987.

Vigiar e Punir: Nascimento da Prisão. Tradução de Raquel Ramalhete. Petrópolis:

FREIRE, Christiane Russomano. A Violência do Sistema Penal Brasileiro Contemporâneo: O caso RDD. São Paulo: IBCCRIM, 2005.

GARLAND, David. As Contradições da Sociedade Punitiva. Revista de Sociologia e Política, Departamento de Ciências Sociais UFPR, 1999.

GOLDENBERG, Mirian. A Arte de Pesquisar: Como fazer pesquisa qualitativa em Ciências Sociais. 8. ed. Rio de Janeiro: Record. 2004.

JÚNIOR, S. F. O. Da Remição. In: SILVA, Jane Ribeiro (Org.). A Execução Penal à Luz do Método APAC. Belo Horizonte: Tribunal de Justiça do Estado de Minas Gerais, 2011.

MARCÃO, Renato. Curso de Execução Penal. 9. ed. São Paulo: Saraiva. 2011.

MAYORA, Marcelo; LINCK, José; PANDOLFO, Alexandre Costi; LUCHESE, Marcelo. Centauros no Central: Análise dos Preconceitos Morais no Imaginário dos Juristas. Revista de Estudos Criminais, Porto Alegre, v. 29, p. 115-128, 2008.

OLIVEIRA, Patrícia de. O Latrocínio na Legislação Brasileira. Revista da Faculdade de Direito da UFG, v. 25, n. 1, 2001. Disponível em: <http://www.revistas.ufg.br/index.php/revfd/article/view/12022>. Acesso em: 27 ago. 2015.

PASTANA, Débora Regina. Cultura do Medo: Reflexões sobre violência criminal, controle social e cidadania no Brasil. São Paulo: Método, 2003.

PERALVA, Angelina. Democracia e Violência: a modernização por baixo. Lua Nova: Revista de Cultura e Política, n. 40/41, 1997. Disponível em: <http:// www.scielo.br/pdf/ln/n4041/a10n4041.pdf>. Acesso em: 12 set. 2015.

RAUTER, Cristina. Criminologia e Subjetividade no Brasil. Rio de Janeiro: Revan, 2003.

RIO GRANDE DO SUL. Poder Judiciário - Corregedoria-Geral da Justiça. Consolidação Normativa Judicial. Disponível em: <https://www.tjrs.jus.br/export/legislacao/estadual/doc/CNJCGJ_Outubro_2012_Prov_18_20 12_VC_.pdf>. Acesso em: 05 set. 2015.

. Decreto 46.534, de 04 de agosto de 2009. Aprova o Regimento Disciplinar Penitenciário do Estado do Rio Grande do Sul. Disponível em: http://www.susepe.rs.gov.br/upload/1321547695_Regimento\%20Disciplinar\%20Penitenci\%C 3\%A1rio\%20atualizado.pdf>. Acesso em: 12 set. 2015.

SANTOS, Juarez Cirino dos. Direito Penal. Parte Geral. 4. ed. Santa Catarina: Conceito Editorial, 2010. 


\section{(1ay) \\ Cademos do Proprama de Pbs-Graduaģio DIREITO/UFRGS}

SCHECAIRA, Sérgio Salomão. Criminologia. 3. ed. São Paulo: Revista dos Tribunai,. 2011.

SCHMIDT, A. Z. Direitos, Deveres e Disciplina na Execução Penal. In: CARVALHO, Salo (Coord.). Crítica à Execução Penal. 2. ed. Rio de Janeiro: Lumen Juris. 2007.

VELO, Joe Tennyson. Criminologia Analítica. Conceitos de Psicologia Analítica para uma hipótese etiológica em Criminologia. São Paulo: IBCCrim, Complexo Jurídico Damásio de Jesus, 1998.

YOUNG, Jock. A Sociedade Excludente: Exclusão Social, Criminalidade e Diferença na Modernidade Recente. Rio de Janeiro: Revan, 2002.

ZAFFARONI, E. Raul; BATISTA,Nilo; ALAGIA, Alejandro; SLOKAR, Alejandro. Direito Penal Brasileiro: Teoria Geral do Direito Penal. Rio de Janeiro: Revan, 2003.

Submissão: 01/08/2016

Aceito para Publicação: 03/01/2017 


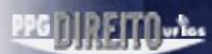

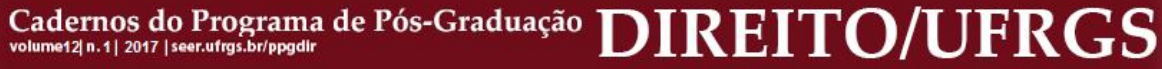

